\title{
HISTORICALAND RECENT OBSERVATIONS IN POLYMER FLOODS: AN UPDATE REVIEW
}

\author{
OBSERVACIONES HISTÓRICAS Y RECIENTES EN INYECCIÓN DE \\ POLIMEROS: REVISIÓN ACTUALIZADA.
}

\author{
OBSERVAÇÕES HISTÓRICAS E RECENTES DE INJEÇÃO DE POLÍMEROS: \\ REVISÃO ACTUALIZADA.
}

Eduardo Manrique ${ }^{1 *}$; Mahmood Ahmadi ${ }^{1}$ and Shirin Samani ${ }^{1}$.

'MI3 Petroleum Engineering, Colorado, United States of America

e-mail: emanrique@mi3pe.com

(Received: Sep. 02, 2016; Accepted: May. 09, 2017)

\begin{abstract}
$\mathrm{P}$ olymer flooding has been the most widely used chemical enhanced oil recovery (EOR) method. The experience gained over the past decades from laboratory studies to project design and field implementation has been well documented in the literature. The main objectives of this paper are to evaluate recent observations of polymer floods that report injection rates leading to pressure values above the formation fracture pressure (FFP), high polymer production, formation of tight emulsions and/or productivity losses.

Based on this review, it can be concluded that no direct evidence exists to support that injecting polymer above the FFP will lead to more polymer production. However, uncertainties associated with the estimation of fracture propagation/dimensions using pressure Fall-Off Tests (FOT) still remain. High polymer production, other than severe channeling, is generally reported in large scale/commercial projects. The impact of oil geochemistry/ composition and water salinity on oil-water-polymer emulsions is commonly overlooked in polymer flood studies. The formation of in-situ emulsions can also explain the injectivity and/or productivity reduction and well test interpretation (i.e. FOT) reported in polymer floods. It was also identified that the OPEX (Operational Expenditures) associated with oil-water separation in the presence of polymer and productivity losses (i.e. workovers, stimulation costs) are generally underestimated. Finally, this review is expected to contribute with the planning, design and implementation of future polymer flood pilots and field expansions.
\end{abstract}

Keywords: Polymer Flooding, Enhanced Oil Recovery (EOR), Chemical EOR, Polymer Production, Emulsions, Voidage replacement, Injection rates, Formation Fracture Pressure, Monitoring, Productivity losses.

How to cite: Manrique, E., Ahmadi,M., Samani,S. Historical and recent observations in Polymer Floods: An Update Review (2017). CT\&F - Ciencia, Tecnología y Futuro, 6(5), 17 - 48.

*To whom correspondence should be addressed 


\title{
RESUMEN
}

L

a inyección de polímeros es el método químico de recobro mejorado con mayor número de implementaciones a escala de campo. La experiencia adquirida en las últimas décadas desde estudios de laboratorio hasta el diseño e implementación de campo ha sido bien documentada en la literatura. El objetivo principal de este trabajo es evaluar observaciones recientes de proyectos de inyección de polímero reportando tasas de inyección por encima de la presión de fractura de la formación, alta producción de polímero, formación de emulsiones viscosas y/o pérdidas de productividad.

Basados en esta revisión, se puede concluir de que no existen evidencias directas de que la inyección de polímero a tasas que impliquen superar la presión de fractura induzcan a una mayor producción de polímeros. Sin embargo, existen incertidumbres relacionadas con la estimación de las dimensiones y propagación de fracturas utilizando pruebas de caídas de presión (FOT). La alta producción de polímero, por razones diferentes a canalizaciones severas, generalmente se reportan en proyectos a escala comercial. Por otra parte, el impacto de la composición y geoquímica del crudo y de la salinidad del agua en la formación de emulsiones agua:petróleo:polímero ha sido subestimado en estudios de inyección de polímeros. La formación de emulsiones in-situ puede explicar la disminución de la inyectividad y/o productividad, y la interpretación de pruebas FOT reportadas en proyectos de campo. Adicionalmente, se destaca que los costos operacionales (OPEX) asociados a la separación de agua:petróleo en presencia de polímero y pérdidas de productividad (p.e. costos por intervención de pozos) son comúnmente subestimados. Finalmente, esta revisión contribuirá con la planificación, diseño e implementación de futuras pruebas pilotos o expansión de proyectos de inyección de polímeros.

Palabras clave: Inyección de Polímero, Recobro Mejorado de Petróleo, Recobro Químico, Producción de Polímeros, Emulsiones, Factor de reemplazo, Tasas de inyección, Presión de fractura, Monitoreo, Pérdidas de productividad.

\section{RESUMO}

\begin{abstract}
injeção de polímeros é com o maior número de aplicações em campo. A experiência que se ganhou - nas últimas décadas, desde estudos laboratoriais até o desenho e aplicação em campo tem sido 1 bem documentada na literatura. $O$ principal objetivo deste trabalho é avaliar recentes observações de projetos de injeção de polímero informando taxas de injeção acima da pressão de fratura da formação, alta produção de polímero, formação de emulsões viscosas e/ou perdas de produtividade.

Baseados nesta revisão, é possível concluir que não há evidencias diretas confirmando que a injeção de polímeros a taxas que exijam ultrapassar a pressão de fratura induza a uma maior produção de polímeros. Contudo, ainda há incertezas em relação à estimativa das dimensões e propagação de fraturas utilizando testes de quedas de pressão (TQP). A alta produção de polímero, por motivos diferentes das canalizações severas, geralmente é relatada em projetos em escala comercial. Por sua vez, o impacto da composição e geoquímica do petróleo bruto e da salinidade da água na formação de emulsões água: petróleo: polímero tem sido subestimado em estudos de injeção de polímeros. A formação de emulsiones in-situ pode explicar a diminuição da injeção e/ou produtividade, e a interpretação de testes TQP relatadas em projetos de campo. Adicionalmente, destaca-se que os custos operacionais (OPEX) associados à separação de água: petróleo na presença de polímero e perdas de produtividade (p.ex. custos por intervenção de poços) são geralmente subestimados. Por fim, esta revisão irá contribuir com o planejamento, desenho e aplicação de futuros testes pilotos ou expansão de projetos de injeção de polímeros.
\end{abstract}

Palavras-chave: Injeção de polímero, Recuperação Avançada de Petróleo, Recuperação Química, Produção de Polímeros, Emulsões, Razão de íons, Fator de substituição, Taxas de injeção, Pressão de Fratura, Monitoramento, Perdas de produtividade. 


\section{INTRODUCTION}

Waterflooding is the most common secondary recovery process worldwide. However, the sweep efficiency of conventional waterfloods can be improved by the injection of polymers. Polymer flooding represents the most mature chemical EOR method as multiple field applications during the past decades exemplify. The main objective of polymer flooding is to improve the mobility ratio (M), defined as the mobility of displacing fluid (water) to the mobility of displaced fluid (oil) ratio. Additionally, polymer injection can accelerate oil production without reducing the residual oil saturation compared to waterflooding (Sorbie, 1991).

Polymer flooding has been evaluated at field scale for more than five decades and is becoming a technology that is gaining great interest within the oil and gas community based on recent laboratory studies and field trials widely documented in the literature. However, despite numerous successes and encouraging results reported in multiple field experiences (Standnes and Skjevrak, 2014), the number of large-scale or commercial floods is still considered relatively low except in Canada (Renouf, 2014) and China (Zhang, Y., Wei, M., Bai, B., Yang, H., \& Kang, W., 2016). Examples of other countries reporting large scale ( $>10$ injectors) or commercial polymer floods include
Albania (Bankers, 2016), Argentina (Buciak, Sancet \& Del Pozo, 2015) and Oman (Choudhuri et al., 2014). Figure 1 shows the general location of pilot and large/ commercial (> 10 injectors) polymer flood projects included in this review.

The growing number of polymer floods during the last decade has contributed to improve the understanding of this technology and to expand its application to reservoirs that were originally discarded based on existing screening criteria. However, the number of projects reporting high polymer production and issues separating produced fluids in the presence of polymer represents an area that needs to be addressed in further detail. The aim of this paper is to evaluate past and recent polymer flood experiences reporting high polymer production and its possible relationship with the formation of viscous emulsions. The formation of emulsions in-situ can also have an important impact on well injectivity and interpreting FOT, aspects that have not been fully addressed in the literature. To achieve the objectives proposed, this paper was divided in four main sections:

- Summary of representative historical polymer flood reviews documented from 1978 to 2016 . The main goal of this review was to identify projects reporting high polymer production and possible formation of tight emulsions and/or productivity losses.

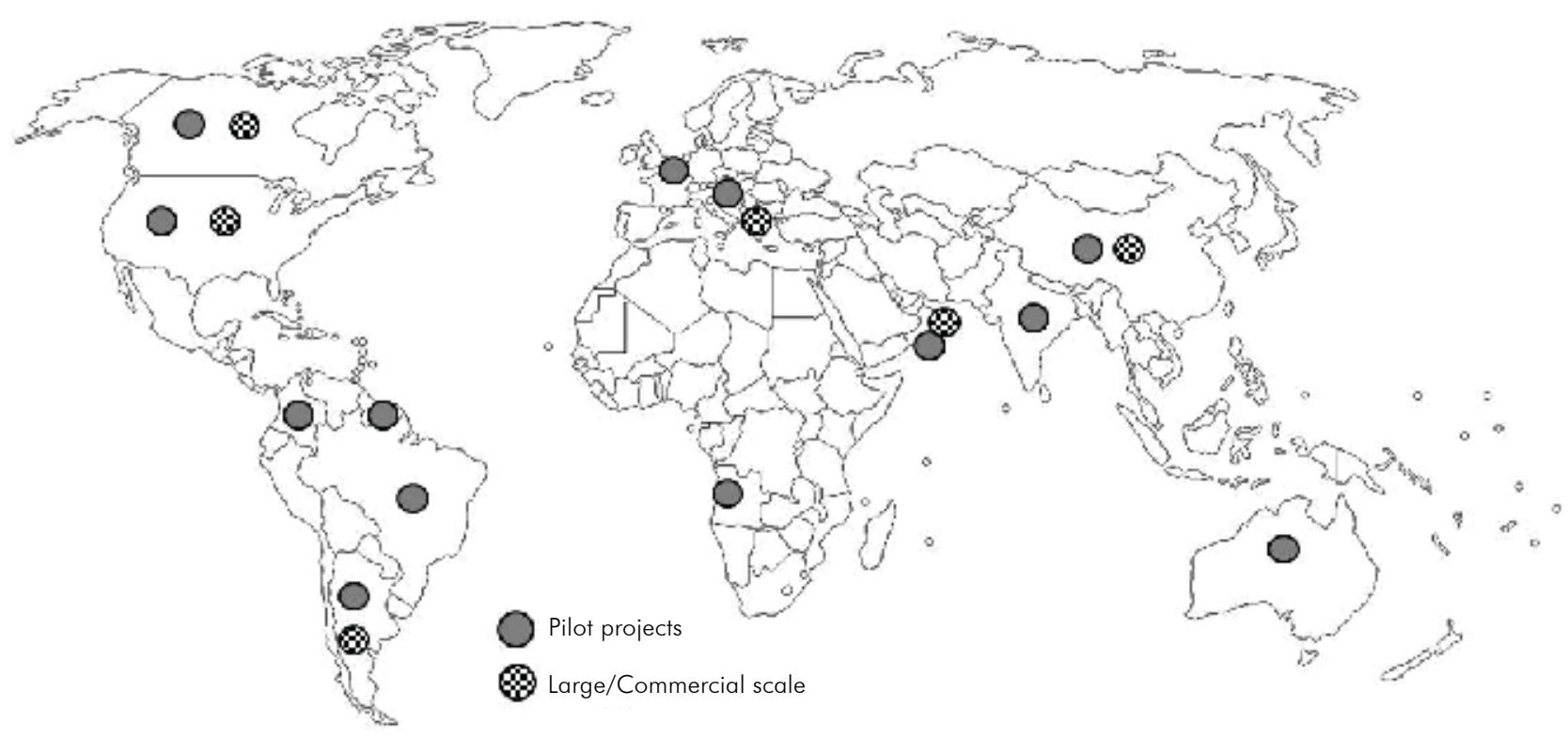

Figure 1. Geographical location of most relevant projects summarized in this review. 
- Review of recent polymer floods reporting injection rates above the FFP to infer its possible relationship with high polymer production. This section will also provide a detailed discussion of the use of pressure Fall-Off Tests (FOT) due to its importance in monitoring programs as well as to estimate fracture propagation and dimensions in polymer floods.

- Evidence of laboratory studies reporting or projects suggesting the formation of oil:water:polymer emulsions in-situ that may explain injectivity reduction, possible misinterpretation of FOT (i.e. viscous emulsions, shear thickening, oil bank formation) and potential productivity losses.

- Polymer floods reporting productivity losses including mitigation strategies and potential impact on operational expenditures (OPEX) and project economics.

In addition to a review of the current status of the technology, the importance of crude oil and brine composition on the formation of spontaneous oil:water emulsions with and without the presence of polymer was also discussed. The analysis performed in this study is expected to provide guidance to expand existing laboratory protocols and revisit the interpretation of FOT with a better understanding fluid:fluid interactions of polymer floods. This study will also contribute with planning, design, implementation and monitoring of future polymer flood pilots and field expansions.

\section{THEORICAL FRAME}

\section{Summary of Historical Reviews on Polymer Floodss}

Chang (1978) provided a historical description and new lab findings of polymer flooding technology. This review included the evaluation of 16 field cases in the U.S and only one that is producing from a Limestone Fm. (N.E. Hallsville Crane Unit, Texas). Chang's paper summarizes seven economic factors that impact PF economics (CAPEX, OPEX, chemical cost, tax regime, oil price, process effectiveness and environmental control). Other costs are associated with well interventions, drilling and completion that will vary depending on reservoir depth and years of operation, among others. Polymer cost reported in this study was \$US $1.35 / \mathrm{lb}$ for polyacrylamide polymers and \$US 2.50/1b for Xanthan Gum. At the time of this review, commercial applications of polymer flooding were limited.

Main conclusions of Chang's study included that polymer injection is relatively simple and low cost to implement, waterflood conversion to polymer flood should be conducted at early stages of water injection and post-flood evaluation is as important as pre-flood studies. Finally, well injectivity, polymer degradation through different mechanisms including chemical additives used for water treatment and the choice of surface equipment were listed among the main technical issues of polymer floods.

Manning, Pope, Lake and Willhite (1983) presented a comprehensive survey of polymer floods. At that time 273 abandoned, current, planned and contemplated polymer projects were identified as part of their study. However, their survey was based on the actual and projected performance of these projects (mainly pilots) from a statistical perspective only. One of the most relevant conclusions was that the findings of this study were in close agreement with the majority of the previous surveys documented in the literature except for the actual oil recovery reported as 3.74 barrels of oil per pound of polymer injected.

Needham and Doe (1987) presented a review and updates of the technology. This review was based on projects documented in the literature including 27 field cases (two in carbonate formations) in the U.S, France and Germany. Among these projects, 16 were also discussed by Chang (1978). Projects were mainly based in polyacrylamide polymers and only three projects used biopolymers. Additionally, five of the projects used aluminum citrate as a crosslinker to enhance permeability reduction effects. This method is also known as CDG ("Colloidal Dispersion Gels") and represents a controversial technology when compared with commonly used polymer.

Needham and Doe also presented a brief summary of polymer flood application based on the Dykstra-Parson (DP) method. From this analysis, the authors concluded the possible limitation of implementing polymer flooding in viscous oils with adverse mobility ratios $(M \geq 100)$ and highly heterogeneous $(\mathrm{DP}>0.8)$ reservoirs. In these cases, projects might not be economically feasible with 
the available polymer products. This study reports the economic and technical successes of polymer flooding in secondary and tertiary applications in sandstone and carbonate reservoirs as well. Secondary floods recovered substantially more oil with lower polymer usage $\left(0.3 \mathrm{lbm} / \mathrm{bbl}\right.$ or $\left.0.1 \mathrm{Kg} / \mathrm{m}^{3}\right)$ than tertiary floods (2 $\mathrm{lbm} / \mathrm{bbl}$ or $\left.5.7 \mathrm{Kg} / \mathrm{m}^{3}\right)$. Therefore, polymer flooding is best applied early in the life of a waterflood (Needham and Doe, 1987).

Du and Guan (2004) presented a summary of lessons learned and experiences gained during 40 years of polymer flooding. However, no specific field projects were listed or mentioned in this study. A general overview of this survey is summarized below:

- Mobility ratio (M) between 0.1 and 42 and oil viscosities up to $126 \mathrm{cP}$.

- Reservoir permeability in the range of 20 and $3,200 \mathrm{mD}$. In reservoirs with lower permeabilities, injectivity reduction might be an economic limitation of polymer floods.

- DP coefficients ranging from 0.28 and 0.80 .

- Economic and technical successes reported in both sandstone and carbonate formations.

- The hottest successful project was reported at $229^{\circ} \mathrm{F}$.

- Polymer flooding generates better results at early stages of a waterflood.

- The injection of small pore volumes of polymer (PV $<0.07$ ) and lack of reservoir pressure maintenance due to poor injectivity are two of the variables highlighted as causes observed for unsuccessful projects.

- Proper reservoir description, laboratory studies, evaluation of biocides and oxygen scavengers and monitoring (i.e. injection and fluid production analysis, well tests) were mentioned among the best practices identified in field implemented polymer floods.

Manrique, Muci and Gurfinkel (2007) published a review of EOR field experiences in carbonate formations in the United States as part of a study sponsored by the U.S Department of Energy. This review presented a summary of 49 polymer floods ( 31 in the State of Texas) documented in the literature from 1960 to 1990. Most of the projects used polyacrylamide polymers with few cases reporting the use of biopolymers (polysaccharides and cellulose polymers) and started at early stages of waterflood projects. Field projects reported the injection of polymer concentrations ranging from 50 to $3,700 \mathrm{ppm}$ (19 to $150 \mathrm{lbm} /$ acre-ft.) and included unsuccessful and successful projects reporting incremental oil recoveries from 0 to $18 \%$ of the Original Oil in Place (OOIP). Despite the number of projects and successes reported in the literature, no additional polymer floods in carbonate formations were documented after 1990.

Gao (2011) summarized five (5) field polymer floods in viscous oil reservoirs $(80-2,000 \mathrm{cP})$. Field results demonstrate technical and economic feasibility of polymer injection in heavy oil reservoirs. The author highlights the importance of water salinity, polymer degradation and adsorption on polymer viscosity. However and despite the limited scope of this review, the study reports that low productivity is one of the issues facing field applications. The author does not provide details describing the possible causes of productivity losses during polymer flooding. This issue will be addressed later in this paper based on laboratory and field experiences.

Mogollón and Lokhandwala (2013) presented a summary of three polymer floods in viscous reservoirs $(>150 \mathrm{cP})$, specifically the Tambaredjo field pilot test (Suriname) and commercial projects in Bohai Bai (Offshore China) and Pelican Lake (Canada). Their study concluded the technical and economic feasibility (based on a probabilistic analysis) of polymer flooding in viscous oils. Among multiple variables evaluated, authors highlight the importance of polymer injection rates on project economics concluding that low polymer injectivity has been overcome using horizontal wells and injecting polymer above the formation fracture pressure.

Saleh, Wei and Bai (2014) developed a statistical analysis of 481 polymer floods (303 successful, 65 discouraging and 103 unevaluated projects). The main objective of this study was to update screening criteria for polymer flooding based on field data. The results of the statistical analysis were based on 250 projects due to duplicated, missing and/or inconsistent information found in the data set. Proposed screening 
criteria presented in this study expand the applicability of polymer flooding to low permeability $(>10 \mathrm{mD})$, reservoir temperatures up to $210^{\circ} \mathrm{F}$ and high oil viscosity $(<5,000 \mathrm{cP})$ reservoirs.

Renouf (2014) summarizes a review of 32 polymer floods in Western Canada mainly in heavy oil fields. Volumes of oil produced from these polymer floods were reported in $1.6 \times 10^{6} \mathrm{~m}^{3}$ in 2011 and $1.7 \times 10^{6} \mathrm{~m}^{3}$ in 2012. Reported incremental oil recoveries ranged from $0.5 \%$ to $14 \%$ of the OOIP. Almost all (30 of 32 ) projects used polyacrylamide (HPAM) polymers. Chauvin South (1987-1992) used a xanthan biopolymer due to high water salinities (TDS of $81,000 \mathrm{mg} / \mathrm{L}$ ) and the Provost Upper Mannville A flood used an associative polyacrylamide polymer after the first stage due to water salinity (TDS $>25,000 \mathrm{mg} / \mathrm{L}$ ) and total hardness (> $450 \mathrm{mg} / \mathrm{L})$.

Almost all projects reported an injectivity reduction averaging $56 \%$ of the pre-polymer flood (water injection) (Renouf, 2014). Polymer injectivity was improved by using horizontal wells. However, this review does not provide major details of injectivity reduction on Voidage Replacement Ratio (VRR) except for two examples briefly mentioned in the study. The first example presented was the project at Brintnell / Pelican Lake where a greater success was attributed to injecting at VRR higher than 1. The second example was the polymer flood at Viking-Kinsella Wainwright B. In this case, injectivity reduction generated a decrease of the VRR from 1 to 0.7 .

The author suggests that the screening criteria for polymer floods are outdated and proposed to expand it to heavy oil reservoirs $\left(>15^{\circ} \mathrm{API}\right.$ and $<5,000 \mathrm{cP}-$ dead oil viscosity) based on the polymer floods reviewed. Finally, injection volumes and rates, and the use of horizontal injectors and water quality represented the most significant operational variables that contributed to the success of polymer floods reviewed. Water quality, polymer integrity and polymer injectivity caused most of the operational difficulties of the projects evaluated.

Delamaide, Bazin, Rousseau and Degre (2014a) presented a summary of Chemical EOR experiences in Canada. However, this brief review will be focused on polymer floods projects for being the main subject of this work. This review of Canadian projects included twelve (12) polymer injection projects at different stages of evaluation ranging from a full field (Pelican Lake / Brintnell) and in progress (i.e. Cactus Lake and Wildmere) to unknown status. Only two (2) of the projects listed in this review reported issues such as severe operational problems (East Bodo) and early polymer breakthrough (Giltedge). The authors provided a summary description of polymer floods at Pelican Lake, Mooney Bluesky A and Seal Bluesky. Main conclusions of this review are summarized below:

- Polymer flooding has proven to be efficient for crude oil viscosities up to $10,000 \mathrm{cP}$ (i.e. Pelican Lake and Seal projects).

- The viscosity of the injected polymer solution for the projects reviewed (Pelican Lake, Mooney and Seal) ranged from 13 to $45 \mathrm{cP}$. This is to achieve a reasonable injection rate in these viscous oil reservoirs (Trade-off between mobility ratio and injection rates).

Standnes and Skjevrak (2014) provided a comprehensive review of polymer field projects. This review included 72 polymer floods (66 onshore and 6 offshore) from 1964 to 2014. Most of the projects used HPAM polymers $(92 \%)$ and the rest reported the use of biopolymers and only one project used hydrophobic associative polymer (Bohai Bay, offshore China). At least 40 projects were reported as successful and 6 were classified as discouraging. A brief summary of the analysis performed by the authors showed:

- Polymer injection in secondary mode shows a higher success rate than injecting polymer in a tertiary mode.

- No major differences were observed between successful and discouraging projects with regards to polymer concentration, resistance factor (RF), residual resistance factor (RRF), polymer retention, well spacing, reservoir temperature, and oil viscosity.

- Emulsion (liquid) polymer has a higher tendency to induce injectivity reduction than powder polymers. However, 7 of 17 polymer floods using emulsion polymers were classified as successful. Only 1 of the discouraging polymer injection projects reported severe injectivity reduction. 
- Discouraging projects either reported significant injectivity reduction (4 of 6 projects), injected less than $20 \%$ of the pore volume ( 3 of 6 projects) and average reservoir permeability was 5 times lower than successful polymer floods $(563 \mathrm{md}$ for successful projects vs. $112 \mathrm{md}$ for the discouraging cases).

- Challenges or issues reported due to early polymer breakthrough (i.e. Wilmington, California) and production were low in general with some projects reporting corrosion and emulsions in the production system. Only one project reported productivity reduction (Bohai Bay, offshore China). However, authors concluded that the number of successful projects outperformed the few discouraging cases reported.

Delamaide (2014) presented a summary of polymer floods in heavy oil reservoirs. The main objective of this study was to describe the evaluation of polymer floods from the screening to commercial expansion. This review includes 10 projects in different countries: Canada (5), Argentina (2), China (1), Oman (1) and Suriname (1). Projects evaluated report several reservoir properties and operating conditions, among others. However, most of the projects reviewed in this study were also discussed by Mogollón and Lokhandwala (2013), Delamaide, Zaitoun, Renard and Tabary (2013), and Standnes and Skjevrak (2014). Hence, no major details of this study will be discussed except for the two areas not widely addressed in previous reviews: oil-polymer emulsions and injection rates above fracture gradients.

The formation of oil-polymer emulsions in Delamaide (2014) review was focused on oil-water separation in surface facilities and the impact of the presence of polymer on emulsion stability. The author summarizes cases reporting injectivity reduction (20$40 \%$ for 5 of the projects reviewed) with respect to water injection. Delamaide (2014) selected the polymer flood in Tambaredjo Field, Suriname, as a case of polymer injection above fracture gradient. Potential risks suggested due to the injection of polymer above fracture gradient, by increasing polymer viscosity, to improve injectivity includes mechanical degradation of polymer, formation of a filter cake (i.e. possible poor polymer filterability at field scale) and negative impact on sweep efficiency, among others. However, this will be discussed later in this paper.
Saboorian-Jooybari, Dejam and Chen (2015) also presented a review of polymer injection in heavy oil reservoirs. This study can be divided in three major areas: a historical review of core floods, review and analysis of field cases and revisiting screening criteria for polymer flooding. Regarding laboratory experiences, the authors presented a historical review of sand packs and corefloods studies in viscous oils (209 - 18,700 cP) reporting incremental oil recoveries between 2.2 and $40 \%$ at variable viscosity ratios and pore volumes injected among many other experimental conditions.

Saboorian-Jooybari, H., Dejam, M., \& Chen, Z. (2015) summarize 11 polymer flood projects in viscous oil reservoirs implemented in different countries: Canada (5), U.S. (2), Argentina (1), China (1), Oman (1) and Suriname (1). All field projects reviewed are well documented in the literature and were also discussed in previews reviews described in this work (Mogollón \& Lokhandwala, 2013; Delamaide, E., Moe, K., Bhoendie, K., Jong-A-Pin, S., \& Paidin, W. R., 2016; Standnes \& Skjevrak, 2014). It is important to remark that this review included two polymer floods in the U.S. implemented during 1960s in Albrecht (Texas) and West Cat Canyon (California) demonstrating the technical and economic feasibility of this technology. Based on the analysis of the projects reviewed, the authors proposed an updated set of screening criteria recommending the use of mobility $(0.31 \mathrm{cP} / \mathrm{mD})$ and oil/polymer viscosity ratio (279) as guidelines when evaluating polymer injection in heavy oil reservoirs.

Sheng, Leonhardt \& Azri (2015) presented a summary of the status of the polymer flood technology. Authors developed a general assessment based on 733 polymer floods implemented in different (24) countries mainly from the U.S (560), China (67) and Canada (50). No major details were presented about the field cases and the study was based on a statistical analysis of the projects reviewed. An average incremental cost of \$US 4.35 per barrel was reported excluding facilities and operating costs.

Their study also proposed a new set of screening criteria for polymer flooding including oil viscosities below $150 \mathrm{cP}$. Main reasons of this relatively low crude oil viscosity is due to the lack of understanding of the mechanisms operating in heavy oil reservoirs. A brief 
analysis of polymer floods in viscous reservoirs (240 - $10,000 \mathrm{cP}$ ) was also performed, evaluating a total of nine projects in Canada (5), Argentina (1), China (1), Suriname (1) and U.S (1). Mixing highly viscous polymer solutions and injectivity reduction were two of the issues highlighted by the authors. Finally, this study summarizes most common problems associated with polymer flooding including formation damage (i.e. polymer adsorption reducing rock permeability), low injectivity (i.e. due to reduced permeability and increased viscosity) that requires of hydraulic fracturing for its improvement, and back-produced polymer that contributes to the formation of stable water/oil emulsions making difficult its separation and the use of produced waters for reinjection.

Zhang, Y., Wei, M., Bai, B., Yang, H., \& Kang, W. (2016) recently presented a survey and data analysis of polymer floods (pilot and commercial) projects implemented in China. This study includes 55 (31 pilots and 24 field scale) projects from 1991 to 2014. Most projects were implemented in Daqing, Henan and Shengli Fields. The main objective of this research was to consolidate and update the screening criteria for polymer flooding based on field applications. Proposed screening criteria are consistent with those proposed in previous studies except for oil viscosity. In this study, polymer injection in reservoirs with oil viscosities lower than $285 \mathrm{cp}$ was recommended.

\section{Brief Discussions on Past Reviews}

After an analysis of past reviews, it can be concluded that polymer flooding is a well-established EOR technology and that the number of successful projects exceeds greatly the number of unsuccessful projects. Despite the successes of claimed cases in multiple polymer flood pilots, the number of commercial projects is still limited. The main reasons attributed to projects reported as discouraging were injectivity reduction, late implementation in mature waterfloods, early polymer breakthrough and/or small pore volume $(<20 \%)$ of polymer injected.

Regarding the applicability of polymer flooding, most reviews are in agreement with most common screening criteria except crude oil viscosity. Sheng et al. (2015) and Zhang, Y., Wei, M., Bai, B., Yang, H., \&
Kang, W., (2016) suggested the applicability of polymer flooding for reservoirs with crude oil viscosities up to $150 \mathrm{cP}$ and $285 \mathrm{cP}$, respectively. This viscosity range clearly contradicts technical and economic feasibility of polymer floods in viscous oils and/or screening criteria proposed by Mogollón and Lokhandwala (2013), Carss (2014), Renouf (2014) and Delamaide et al. (2014a). Sheng et al. (2015) explained their disagreement as a lack of understanding of the mechanisms operating in heavy oil reservoirs and based on their interpretations, discussing some aspects of the Pelican Lake polymer flood documented in the literature. Additionally, Sheng et al. (2015) attributed the use of polymer injection in viscous oil reservoirs to high oil prices, modest polymer prices, and the increased use of horizontal injectors. This point of view can be only justified due to the limited number of commercial projects but this is also valid for medium and light oil reservoirs. However, Sheng et al. (2015) did not present solid arguments to discard the applicability of polymer flood technology in heavy oil reservoirs. In the case of Zhang et al. (2016), the proposed criteria for crude oil viscosity (up to $285 \mathrm{cP}$ ) to consider polymer injection was based exclusively on the experience in China, including 24 field scale projects (i.e. Bohai Bai and Daqing Fields). Figure 2 shows the average permeability $(\mathrm{K})$ vs. the average oil viscosity $\left(\mu_{0}\right)$ of approximately 400 polymer floods documented in the literature. It is clear that most projects (highlighted with the dashed line rectangle) have been implemented in reservoirs with $\mu \mathrm{o}$ and $\mathrm{K}$ below $100 \mathrm{cP}$ and 1 Darcy, respectively. However, Bohai Bai "A", Patos-Marinza and Pelican Lake are three of the few ongoing commercial scale polymer floods in reservoirs with viscosities above the proposed values by Sheng et al. (2015) and Zhang et al. (2016). Hence, crude oil viscosity should not be used as the only reference to discard the applicability of polymer flooding in a given reservoir based on ongoing commercial projects.

There is a wide consensus recommending polymer injection at early stages of water injection or as a secondary method. As to when to start polymer injection, this represents a common question in the oil and gas community evaluating this chemical EOR method. There are multiple criteria that can help to decide the timing to start polymer injection (Secondary vs. early stages of waterflooding). Some recommended criteria include, but are not limited to: 


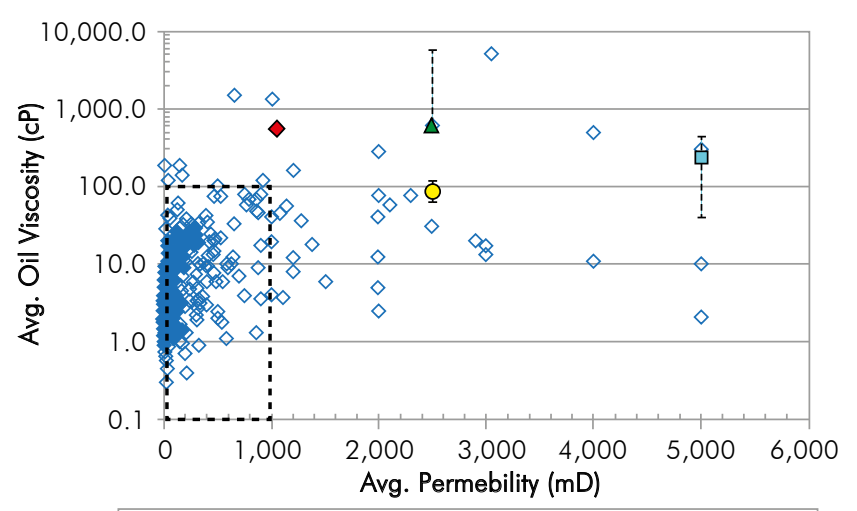

$\neg$-Bohai Bai O Marmul $\Delta$ Pelican Lake $\diamond$ Patos Marinza

Figure 2. Average viscosity-permeability plot of polymer floods implemented at a pilot or large/commercial scale.

- If there is evidence of fill-up during water injection (typically observed in Hall Plots) or the reservoir was highly depleted during primary production (i.e. presence of free gas), delayed polymer injection might be recommended.

- Fill-up the reservoir with polymer instead of water can represent a waste of money and the presence of free gas may cause injectivity reduction (i.e. trapped gas effects).

$\circ$ These effects are expected to be less important in viscous oil reservoirs (i.e. oils with low gas in solution).

- Start with water injection can be useful for various reasons:

- Understand reservoir connectivity and calibrate the geologic/numerical models used to predict polymer flood performance. This can also contribute addressing possible conformance issues due to channeling effects before polymer injection starts.

- Validate and establish a reference of water injectivity, especially in reservoirs with the presence of swelling/sensitive clays.

- Evaluate possible reservoir souring effects (Khatib \& Salanitro, 1997; Larter \& Aplin, 1995) that can impact production operations (i.e. generation of $\mathrm{H}_{2} \mathrm{~S}$ ).

- Estimate incremental oil generated by polymer injection. If not feasible, considering running parallel water and polymer flood pilots as secondary recovery method, could be an option.
From the previous studies, it can be noticed that in the last two decades no major advances in polymer flood technology have been reported in carbonates, high temperature $\left(\mathrm{T}>200^{\circ} \mathrm{F}\right)$ and offshore reservoirs. After the polymer floods reported in U.S. carbonate formations by Manrique, E., Muci, V. E., \& Gurfinkel, M. E. (2007) there are no major advances or documented field projects evaluating polymer flooding in carbonate, dolomitic or limestone formations. Most of the activities of polymer injection in carbonates have been focused on the evaluations in laboratory and simulation studies (Han, Fuseni, Zahrani \& Wang, 2014; Masalmeh, Wei, Blom \& Jing, 2014; Raza, Shoaib, Al Sumaiti \& Al Hassan, 2015). It is worth mentioning the recent Single Well Tracer Tests (SWTT) and pilot designs reported in carbonate fields in Abu Dhabi and Kuwait (Abdullah, Tiwari \& Pathak, 2015; Bursaux, R., Peltier, S., Nguyen, M., Romero, C., \& Morel, D., 2016; Levitt et al., 2016). However, both projects are evaluating surfactant technologies (SP or ASP). Hence, these projects will not be discussed in this study, which focuses on the evaluation of polymer flood technology only.

With regards to polymer floods at HT reservoirs ( $\mathrm{T}$ $>200^{\circ} \mathrm{F}$ ), experiences found are mainly focused on lab evaluations and numerical simulation studies (Gaillard et al., 2015; Zhuoyan et al., 2015). Although there are some ongoing field evaluations on HT reservoirs, no details of these evaluations have been documented in the literature. The main challenge of HT polymer floods is that the high well spacing which requires large volumes of polymer in reservoirs with thick net pays and/or long residence times in the formation will potentially impact the polymer stability (i.e. thermal degradation). Additionally, HT reservoirs are typically associated to deep formations and infill drilling might be too costly to justify polymer injection.

Polymer injection offshore has not been reported in recent times (Alvarado \& Manrique, 2013). Bohai Bai in China (Xiaodong et al., 2011) and Dalia in Angola (Morel, D., Vert, M., Jouenne, S., Gauchet, R., \& Bouger, Y., 2012 and Morel, D., C., Zaugg, E., Jouenne, S., Danquigny, J. A., \& Cordelier, P. R., 2015) represent the most relevant offshore polymer projects documented in the literature. Captain Field offshore UK is another important polymer flood project 
injecting liquid polymers; however, its documentation is scarce (Chevron 2014 \& 2015; Poulsen, $2009 \& 2010$ ). Dwarakanath et al. (2016) recently reported a study evaluating the permeability reduction in porous media (Bentheimer rock, Ottawa sand and unconsolidated field sand) due to the use of liquid polymers. This study also reports remediation formulations to improve injectivity.

Finally, some areas that have not been fully addressed in past polymer floods reviews include the impact of injection rates at pressures above the formation fracture pressure, Voidage Replacement Ratios (VRR), the formation of oil-polymer emulsions in the reservoir and possible productivity losses. These areas represent the main objective of this study and will be discussed in the following sections of this paper.

\section{Recent Observations in Polymer Floods}

Injectivity reduction, oil:water separation in the presence of high polymer concentrations and productivity losses to a lesser extent have been topics of discussions in recent polymer flooding projects and reviews. With an increased interest in pilot implementation, ongoing pilots and field expansion evaluations, these topics have become critical areas of discussion with several operators as part of their risk and uncertainty evaluation. Therefore, this paper will try to address these topics based on lab and field experiences documented in the literature.

\section{Polymer Injection Rates}

Before discussing the injection rate strategies reported in polymer floods, it is important to briefly consider the concept of Voidage Replacement Ratio (VRR). VRR is the ratio of reservoir barrels of injected fluid to reservoir barrels of produced fluids. Plots of VRR vs. time are typically used to evaluate pressure maintenance by water (or gas) injection. When VRR is equal or higher than 1 the reservoir pressure is being maintained/increased. IfVRR is less than 1 the reservoir pressure is declining (Baker, 1998; Terrado, Yudono \& Thakur, 2006; Thakur \& Satter, 1998). Although reservoir development strategies may vary among companies, in some countries VRR is used by regulatory agencies as a means of monitoring the impact of the field development on energy/resources management and the environment. Therefore, the injection rate defined for polymer floods will also depend on the regulations for a given country. For example, the Alberta Energy Regulator (AER) in Canada generally specifies a VRR of 1 to fully maintain the reservoir pressure, and limits the wellhead injection pressures (Directive 51) generally to $90 \%$ of the fracture (formation partition) pressure (Alberta Energy Regulator, 1994). Additionally, wells included in EOR schemes (Directive 065) may be subject to further injection pressure limitations (Alberta Energy Regulator, 2014).

The strategy of VRR $\geq 1$ (instantaneous or cumulative) is a well-established concept for an optimum reservoir management of waterfloods in medium and light oils. However, it has been proposed that this concept might not be valid for waterfloods in heavy oil reservoirs where VRR $<1$ could be beneficial. The potential advantages of this strategy $(\mathrm{VRR}<1)$ to improve oil recovery in heavy oil waterfloods is due to the activation of one or more of the following mechanisms: solution gas drive, foamy oil drive, in-situ emulsification and three-phase relative permeability (Brice, Ning, Wood \& Renouf, 2014; Delgado, Vittoratos \& Kovscek, 2013; San Blas and Vittoratos, 2014; Vittoratos and Boccardo, 2015; Vittoratos, Coates \& West, 2011; Vittoratos, Zhu \& West, 2014). The proposed approach of optimum VRR for waterfloods in heavy oil reservoirs can impact polymer floods performance and should be considered when evaluating the technical and economic feasibility of polymer flooding in viscous oil reservoirs.

Injectivity reduction is the most common issue reported in polymer floods leading to a decrease in the VRR $(<1)$. A decrease in injectivity should be expected due to the higher viscosity of polymer solutions compared to water. However, injectivity reduction documented in several projects was reported as manageable. It is also common that most of the injection wells are fractured during waterflood operations before polymer injection starts. Reported strategies to mitigate injectivity reduction in polymer floods include:

- Use of horizontal wells

- Well stimulation (i.e. acid and frac jobs)

- Flow back injectors

- Increase perforations shots per unit length

- Decrease polymer concentration (trade-off mobility control vs. injectivity) 
Examples of these strategies to manage injectivity reduction in recent polymer floods have been reported in Caen (Liu, Adegbesan \& Bai, 2012), El Corcobo (Hryc, A., Hochenfellner, F., Paponi, H., Puliti, R., \& Gerlero, T., 2013), Mangala (Kumar, P., Raj., R., Koduru, N., Kumar, S., \& Pandey, A., 2016), Medicine Hat Glauconitic C Pool (Batonyi, Thorburn \& Molnar, 2016), Patos-Marinza (Carss, 2014; Jacobs, 2015; Bankers, 2016), Pelican Lake (Delamaide, Tabary, Rénard \& Dwyer, 2014b), Yariguí-Cantagallo (Maya et al., 2015) and different fields in Western Canada (Renouf, 2014). It is also important to remark that water quality represents a good practice and recommendation in polymer floods reviewed. Therefore, a detailed monitoring (QA/QC) of water quality (i.e. oil content, chemical treatment, suspended solids, etc.) is key for the success of the project and the proper understanding of well injectivity before ascribing injectivity losses to polymer injection (Bennion, Bennion, Thomas \& Bietz, 1998; Glasbergen, Wever, Keijzer \& Farajzadeh, 2015).

Although the decrease of the VRR $(<1)$ due to injectivity reduction can impact project economics, this does not mean that polymer floods are or will be uneconomic under this development strategy. The decrease of VRR oftentimes comes with a positive oil response (Liu, et al., 2012; Batonyi, A., Thorburn, L., \& Molnar, S., 2016). However, since 2009 there is a new trend of some polymer floods injecting above the FFP to improve well injectivity and to sustain VRR $\geq 1$. These projects will be the main topic of the discussion of this section. Table 1 summarizes some characteristics of the polymer floods in Australia (Windalia Field Pilot), Austria (Matzen -8 TH Horizon pilot), Oman (Marmul commercial flood) and Suriname (Tambaredjo Field pilot). All these projects have been reported as successful and/or show promising results with ongoing evaluation for possible field expansions.

Polymer floods injecting above frac gradient (Table 1) show important differences in reservoir permeability and crude oil viscosities. Hence, the first conclusion is that this injection strategy can be considered in a broad range of reservoir conditions that meet most criteria for polymer flooding except for reservoir permeability. For example, Windalia Field will not meet the existing criteria of reservoir permeability for polymer injection. All four projects listed in Table 1 are well documented in the literature and references can be found at the end of this paper. Therefore, this section will provide a brief summary of the background of each of these projects focusing the attention on common observations, possible uncertainties associated to the estimation of fracture geometries and the concentration of polymer production.

Windalia field (Fletcher and Morrison, 2008; Haynes, Clough, Fletcher \&Weston, 2013) is a high clay content sandstone and low permeability light oil $\left(36^{\circ} \mathrm{API}\right)$ reservoir $\left(65^{\circ} \mathrm{C}\right)$ in Australia. Windalia reservoir has an OOIP of 819 MMbbls and it is under line-drive water injection since 1967 reporting a recovery factor of $37 \%$. Waterflooding was operated injecting above the frac gradient to maintain voidage. Therefore, vertical injectors were already fractured before polymer injection started. The polymer flood pilot was run for 2 years with 3 wells (From May 2009 to July 2011) using a variable polymer concentration of a low molecular weight (MW) HPAM. In the pilot, two injectors were fractured with proppants, and the third one was allowed to inject above the fracture pressure. The main objective of this project was to promote in-depth flow diversion rather than mobility control. Despite polymer injection rates one out of the three injectors experienced a strong injectivity reduction. The pilot project was defined as successful by the operator but no additional information about project expansion or production performance has been documented since 2013. Finally, Haynes, A. K., Clough, M. D., Fletcher, A. J. P., \& Weston, S., (2013) reported that the rate at which fracture growth occurred was unknown.

Table 1. Summary information of polymer floods injecting above frac gradient (FFP).

\begin{tabular}{|ccccc|}
\hline Field, Country & Permeability & Net Pay (ft.) & Injector(s) & Oil Visc. (cP) \\
\hline Windalia, Australia & 5 md (with $20+$ streaks) & $98.4(30 \mathrm{~m})$ & Vertical & 0.65 \\
\hline Matzen (8 TH), Austria & $500 \mathrm{md}$ (Avg.) $(10-3,000 \mathrm{md})$ & $65.6(\approx 20 \mathrm{~m})$ & Vertical & $19-27$ \\
\hline Marmul, Oman & $100-5,000 \mathrm{md}$ & 65.6 (Avg. $20 \mathrm{~m})$ & Mostly verticals \& 3 Horizontals & 90 \\
\hline Tambaredjo, Suriname & T1: 4,000 Avg. (1 - 12 D) & 20 (T1 Sand) & Vertical & $400-600$ \\
\hline
\end{tabular}


Matzen Field ( $8 \mathrm{TH}$ horizon) is a sandstone viscous $\left(20^{\circ} \mathrm{API}\right)$ oil reservoir $\left(50^{\circ} \mathrm{C}\right)$ in Austria (Chiotoroiu, Peisker, Clemens \& Thiele, 2016; Clemens, T., Deckers, M., Kornberger, M., Gumpenberger, T., \& Zechner, M., 2013; Laoroongroj, Zechner, Clemens \& Gringarten, 2012; Laoroongroj, A., Lüftenegger, M., Kadnar, R., Puls, C., \& Clemens, T., 2015; Lüftenegger, Kadnar, Puls \& Clemens, 2015; Sieberer, Jamek \& Clemens, 2016; Zechner, Clemens, Suri, \& Sharma, 2015). Production from the $8 \mathrm{TH}$ horizon started in 1951 and waterflood in 1960. The estimated recovery factor was $26 \%$ and water cuts reached to $96 \%$ before polymer injection started. The pilot project includes 2 irregular "unconfined" patterns sharing one producer. Polymer injection started in January 2012 (well SC-1 until April 2013) and June 2012 (well S-81). The operator defined a strategy of constant injection rate of $220 \mathrm{~m} 3 / \mathrm{d}(\approx 1,400$ $\mathrm{bbl} / \mathrm{d}$ ) adjusting polymer concentration to keep injecting above the FFP. Based on the results of the pilot project the operator is evaluating possible options for the expansion of polymer flooding (Sieberer, M., Jamek, K., \& Clemens, T., 2016).

Marmul field is a sandstone viscous $\left(22^{\circ} \mathrm{API}\right)$ oil reservoir $(90 \mathrm{cP})$ and a well-documented commercial polymer flood in Oman (Al Azri, 2012; Al-Kalbani et al., 2014a; Al-Kalbani, Mandhari, Al-Hadhrami \& Philip, 2014b; Al-Kalbani et al., 2014c; Al-Saadi et al., 2012; Al-Saadi, Al-Subhi \& Al-Siyabi, 2014; Choudhuri and Al-Rawahi, 2008; Choudhuri et al., 2013; Choudhuri et al., 2014; Koning and Mentzer, 1988; Shuaili et al., 2012; Thakuria et al., 2013; Zwaan and Valdez, 2015). This field was discovered in 1956 and started commercial production in 1980. Marmul (Al Khlata reservoir) is a very complex and heterogeneous reservoir with the presence of fractures/faults plus adverse mobility ratio. Water injection started in 2005 and the expected recovery factor was estimated in $27 \%$. The first polymer pilot was implemented between 1988 and 1989 indicating promising results. However, it was not expanded due to a low oil price environment. Lately, the expanded plan for polymer injection started in February 2010 injecting polymer targeting a viscosity of $15 \mathrm{cP}(10-25 \mathrm{cP})$. The project includes a total of 27 injectors (26 in Al Khlata and 1 in Haima Formations) and a total of 126 producers. Although some of the injectors were already fractured during the waterflood, polymer injection was planned to be "under controlled fracturing conditions since a matrix development will result in extremely low injectivity". Choudhuri et al., (2014) reported that the fracture length should not exceed $30 \%$ of the spacing to minimize the risk of direct inter-well communication impacting negatively the sweep efficiency.

Tambaredjo field is a heavy $\left(16^{\circ} \mathrm{API}\right.$ and $300-1,100$ $\mathrm{cP})$ oil and relatively unconsolidated sandstone reservoir in Suriname (Delamaide et al., 2016; Manichand, R., Mogollón, J. L., Bergwijn, S., Graanoogst, F., \& Ramdajal, R., 2010; Manichand, R. N., Moe, K. P., Gil, L., Quillien, B., \& Seright, R. S., 2013; Manichand and Seright, 2014; Moe, Manichand \& Seright, 2012). Tambaredjo is described as a highly heterogeneous reservoir with a permeability contrast higher than 10:1 ( $\mathrm{T} 1$ sand is a free crossflow reservoir). This field reports a good primary recovery $(\approx 30 \%$ of the OOIP) being solution-gas drive and compaction the main production mechanisms. Tambaredjo (Sarah Maria) polymer flood pilot area does not report active water drive or waterflood project. The pilot area consists of three 5 -spot patterns ( 3 injectors and 9 offset producers) and the first well (1M101) started polymer injection in September 2008, the second injector (1N062) in May 2010 and the third (1M052) in June 2011 (Manichand and Seright, 2014). The injection strategy considered a variable injection rate (160-450 bbl/d) and an increase of polymer viscosity/concentration (45 cp@1,000 ppm; 85 cp@1,350 ppm and; 125 cP@2,300 ppm) over time. As of 2016, polymer had been injected in approximately $75 \%$ of the PV of the Tambaredjo pilot project reporting good oil response as recently reported by Delamaide et al. (2016).

As can be noticed, all four projects summarized above considered different strategies to inject polymer above frac gradient and also striving to control as much as possible the polymer channeling due to possible propagation of induced fractures. The differences in injection strategy are also expected due to the wide range of reservoir properties of the evaluated projects (Table 1). Windalia polymer flood required polymer injectivity improvement to promote near wellbore fractures in a low permeable formation using a low MW polymer. On the contrary, Matzen, Marmul, and Tambaredjo are polymer floods injecting above frac gradient in reasonable high permeability formations to improve well injectivity and reduce polymer mechanical degradation (Moe, K. P., Manichand, R. N., \& Seright, R. S., 2012; Seright, 
2010; Thakuria et al., 2013; Zechner, M., Clemens, T., Suri, A., \& Sharma, M. M., 2015). Matzen, Marmul, and Tambaredjo polymer floods are using the same high MW polymer and some additional common observations include:

- Produced polymer shows 40 to $80 \%$ reduction in polymer MW - from 20-18 MDa (injected) to 3-12 MDa (Al-Kalbani et al., 2014b; Lüftenegger, M., Kadnar, R., Puls, C., \& Clemens, T., 2015; Manichand et al, 2013).

- All project report a reduction in water mobility and good oil response despite the lower MW of the polymer produced (Al-Saadi et al., 2014; Lüftenegger et al., 2015; Manichand et al, 2013).

The wide range in the MW reduction of produced polymers can be attributed to the differences in reservoir properties, water quality, injection strategies, well completions and artificial lift systems (i.e. beam, progressive cavity and sucker rod pumps), among others. However, all projects reported positive oil response. Therefore, it is difficult to provide any additional interpretation based on the information available. On the other hand, the increases of polymer hydrolysis and reduction in MW of produced polymers have not been widely reported in the literature. Standnes and Skjevrak (2014) included few examples reporting these effects in polymer floods in China (i.e. Daqing, Shengli and Shuanghe fields), Germany (i.e. Hankensbuettel-Sued) and the U.K (Beatrice Field). However, the information is scarce and more detailed studies will be required to predict polymer stability deep in the reservoir. Jouenne, Chakibi and Levitt (2015) developed a study describing the degradation kinetics of different HPAM solutions flowing through different geometries including porous media. Some of the results reported in this study include that degrading polymer solutions to a same level using different geometries will not necessarily generate the same MW distribution. However, degraded polymers showed better injectivity characteristics and tolerance to shear.

Regarding the control of fracture propagation, the importance of monitoring to control flood sweep efficiency and avoid early polymer breakthrough is recognized. Fracture extension as a result of the polymer floods, which are described by several authors, varies from few tenths (i.e. Matzen and Tambaredjo Field) to hundreds of feet (i.e. Windalia Field). For example, the strategy in Marmul polymer flood is that fracture propagation should not exceed 1/3 of the spacing between injector and producer (Shuaili, et al., 2012). The general approach before polymer injection start is to develop a step rate test to identify the FFP (frac gradient) and run Fall-Off Tests (FOT) to define the baseline under waterflooding. To control the fracture extension and/or estimate fracture dimensions the following monitoring methods have been documented:

- Well injectivity (BPD/psi vs. injection rates) and bottom-hole pressures. This is the main monitoring strategy reported for Tambaredjo Field (Manichand et al., 2010; Moe et al., 2012).

- Time-lapse FOT (Haynes et al., 2013; Mahani, H., Sorop, T., Van den Hoek, P., Brooks, D., \& Zwaan, M., 2011; Shuaili, et al., 2012; Thakuria et al., 2013; Van den Hoek et al., 2012).

- FOT is also useful as a monitoring tool to estimate the displacement front, in-situ polymer viscosity and mobility reduction due to polymer injection (Clemens et al., 2013; Laoroongroj et al., 2012; Lüftenegger et al., 2015; Shuaili, et al., 2012; Thakuria et al., 2013; Van den Hoek et al., 2012).

- Time-lapse FOT combined with time lapse temperature $\log$ s to better estimate fracture heights comparing geothermal gradient with static temperature profiles (Shuaili, et al., 2012; Zwaan and Valdez, 2015).

An important difference identified during FOT was the approach followed to run this well test. FOT performed with surface shut-in makes difficult to infer induced fracture geometries (Haynes et al., 2013; Lüftenegger et al., 2015). FOT's implemented using downhole pressure gauges permanently installed in the injectors offers more detailed pressure readings over time reducing the effects of wellbore storage and liquid level drop in the wellbore due to reservoir depletion (Shuaili et al., 2012; Van den Hoek et al., 2012). However, this will be further discussed at the end of this section.

Recognizing the existence of uncertainties of geologic interpretations and up-scaling approaches, the use of injectors already fractured during waterflood operations and estimating induced fracture geometries during polymer injection through various well testing methods, among others, it is important to evaluate the 
impact of these uncertainties on polymer production and project economics. High polymer production should be expected in commercial scale (i.e. Brintnell/ Pelican Lake and Marmul) polymer floods. However, the experience gained with the increased number of polymer flood projects shows that the difficulties experienced due to high polymer production require more attention, especially for projects considering field expansions. Polymer production can occur due to multiple reasons (i.e. presence of thief zones, reduced well spacing, fracture propagation, etc.). One possible uncertainty in polymer floods injecting above frac gradients could be the potential communication of induced fractures with high permeability zones (i.e. natural fractures, thief zones) that may lead to the production of high polymer concentrations. This uncertainty is also supported by previous laboratory studies evaluating fracture behavior during polymer injection in unconsolidated sandstones (Khodaverdian, Sorop, Postif \& Van den Hoek, 2010; Zhou, Dong, de Pater \& Zitha, 2010). Table 2 compares polymer concentration injected vs. produced of polymer floods injecting above the FFP.

Based on the information available, it is impossible to establish a direct correlation between polymer injection rates above frac gradient and polymer production. However, Marmul (commercial scale) and Tambaredjo (pilot scale) polymer floods report high polymer production suggesting some level of channeling/ conformance problems. Channeling effects are more pronounced in latest two patterns (1N062 and 1M052) of Tambaredjo field. High polymer production experienced in this pilot project may require additional evaluations before a possible field expansion in a reservoir that also reports a high frequency of tubing failures and a corrosiveness nature of produced fluids (Nurmohamed, Chin, Lien \& Kisoensingh, 2014).

\section{Summary discussion}

Injectivity reduction should be expected during polymer flooding. However, before attributing injectivity losses to polymer injection verify and carefully monitor water quality and chemical treatments of injection waters must be validated. Reported strategies to mitigate the injectivity reduction in polymer floods were summarized at the beginning of this section. On the other hand, the decrease of VRR $(<1)$ as a consequence of injectivity losses generally comes with a positive oil response and a reduction of water cuts. This development strategy is the most common in past and ongoing polymer floods. In the case of viscous oil reservoirs, the evaluation of the benefits operating at VRR $<1$ needs to be considered when evaluating technical and economic feasibility of polymer flooding based on the observations documented in the literature (Brice, B., Ning, S., Wood, A., \& Renouf, G., 2014; Delgado, D. E., Vittoratos, E., \& Kovscek, A.

Table 2. Example of polymer production in projects injecting above the FFP (frac gradient).

\begin{tabular}{|c|c|c|c|}
\hline Field, Country & $\begin{array}{l}\text { Polymer Conc. } \\
\text { Injected (ppm) }\end{array}$ & $\begin{array}{l}\text { Polymer Conc. } \\
\text { Produced (ppm) }\end{array}$ & Comments \\
\hline Windalia, Australia & 400 (Avg.) (Max. 750) & Not observed as 2013 & $\begin{array}{l}3 \text { Injectors in a line-drive arrangement with variable spacing } \\
(\approx 280-300 \mathrm{~m}) \text {. No polymer production can be attributed } \\
\text { to the low reservoir permeability and high polymer retention } \\
\geq 130 \mathrm{mg} / \mathrm{g} \text { ) reported in coreflood experiments (RRF: } 8-40 \text { ) }\end{array}$ \\
\hline Matzen (8 TH), Austria & $500-1,000$ & $\approx 30-110$ & $\begin{array}{l}200-300 \text { m well spacing. Polymer breakthrough } \\
\text { reported approximately after a year the injection started } \\
\text { (Polymer breakthrough was observed several months later } \\
\text { than tracer breakthrough before the polymer flood started) }\end{array}$ \\
\hline Marmul, Oman & $1,000-1,500^{(a)}$ & $\begin{array}{l}\approx 500 \text { (Avg.) } \\
\begin{array}{c}\text { (Some wells exceeds } \\
1,000 \text { ppm) })^{(a)}\end{array}\end{array}$ & $\begin{array}{l}\text { Different well patterns (9-spot; } 5 \text {-spot and irregular with } \\
\text { horizontal injectors) with variable spacing }(300-600 \mathrm{~m}) \text {. } \\
\text { Average production of polymer concentration reported after } \\
\text { approximately } 0.21 \mathrm{PV} \text { of polymer injected. Increasing } \\
\text { trend in polymer production is expected at commercial } \\
\text { scale (Polymer production reported between } 4 \text { to } 8 \text { months) }\end{array}$ \\
\hline Tambaredjo, Suriname & $1,000-2,300$ & $200-1,050$ & $\begin{array}{l}\text { Three } 5 \text {-spot pattern }(\approx 100-200 \mathrm{~m} \text { spacing }) \text {. Polymer } \\
\text { concentration reported varies based on the starting date of } \\
\text { polymer injection of each pattern. Sharp polymer production } \\
\text { reported in approximately less than } 6 \text { months for the last two } \\
\text { patterns }{ }^{(b)} \text {. }\end{array}$ \\
\hline
\end{tabular}

(a) Estimated from polymer production concentration (Figure 12, Thakuria et al., 2013)

(b) Estimated from Manichand and Seright, 2014 (Figures 6 \& 8) and from Delamaide et al., 2016 (Fig. 9) 
R., 2013; San Blas and Vittoratos, 2014; Vittoratos and Boccardo, 2015; Vittoratos, E. S., Coates, R., \& West, C. C., 2011; Vittoratos, E. S., Zhu, Z., \& West, C. C., 2014).

Assuming that injection rates above the formation fracture pressure (FFP) and VRR are not conditioned by regulatory agencies (i.e. Canada), the design and operation of polymer floods injecting below frac gradient are recommended. Authors of this paper understand that there are reasons to consider injection rates above the frac gradient. Windalia polymer flood pilot represents a good example (Haynes et al., 2013). This project tested the technology beyond recommended screening criteria with respect to the reservoir permeability. Windalia and the projects reviewed in this section considering injection rates above frac gradient reports good and promising oil responses. In the case of Marmul polymer flood, incremental oil recovery factor has been estimated in $10 \%$ of the OOIP (Al-Saadi, F. S., Al-Subhi, H. A., \& Al-Siyabi, H., 2014). However, the decision to consider this injection strategy will vary from company to company (privately or state own) and/or for a given country. Finally, if polymer injection above the frac gradient is justified the best strategy is controlling fracture growth by injection rates rather than increasing polymer concentration. This strategy was considered for Matzen polymer flood pilot. Injection rates were kept constant above the frac gradient constrained by the wellhead pressure operating conditions tapering polymer concentrations (Clemens, T., Deckers, M., Kornberger, M., Gumpenberger, T., \& Zechner, M., 2013; Lüftenegger et al., 2015).

Regardless injection rates used in polymer floods, polymer production should be considered as one of the key variables when planning and implementing polymer injection projects. Accelerating oil response by increasing injection rates above frac gradient, polymer concentrations or both are not the only drivers of polymer flood economics. Polymer production and its impact on water-oil separation costs and potential productivity losses (to be discussed later in this paper) are additional factors that can heavily impact the OPEX and hence project economics. Trade-off between mobility and injectivity improvement can be managed. Canadian polymer floods are a good example of this reporting the injection of polymer solutions between 20 and $50 \mathrm{cP}$ in viscous oil (up to 7,500 $\mathrm{cP}$ ) reservoirs and recovery factors up to $14 \%$ of the OOIP (Delamaide,
2014; Renouf, 2014). These observations have been also reported in recent coreflood studies using viscous crude oils (Fabbri et al., 2015; Romero et al., 2013; Skauge et al., 2014).

The evaluation of polymer production is also a critical variable when considering polymer flood expansions. It is common to start polymer flood pilots with sources of relative good water quality (i.e. aquifers and make-up waters). However, water strategies might be different for project expansions due to multiple reasons including environmental regulations and constraints in surface facilities, among others. If polymer flood expansion will rely in make-up or $100 \%$ produced waters, the presence of polymer in production facilities will represent an important variable to consider from the early stages of planning and evaluation. Figure 3 shows a schematic example that operators can face when evaluating the expansion of polymer flood projects. During pilot scale stages water sources for injection are generally flexible. This flexibility can be limited during project expansions influencing the decision-making process for the deployment of larger scale polymer floods (i.e. full field vs. expansion by phases).

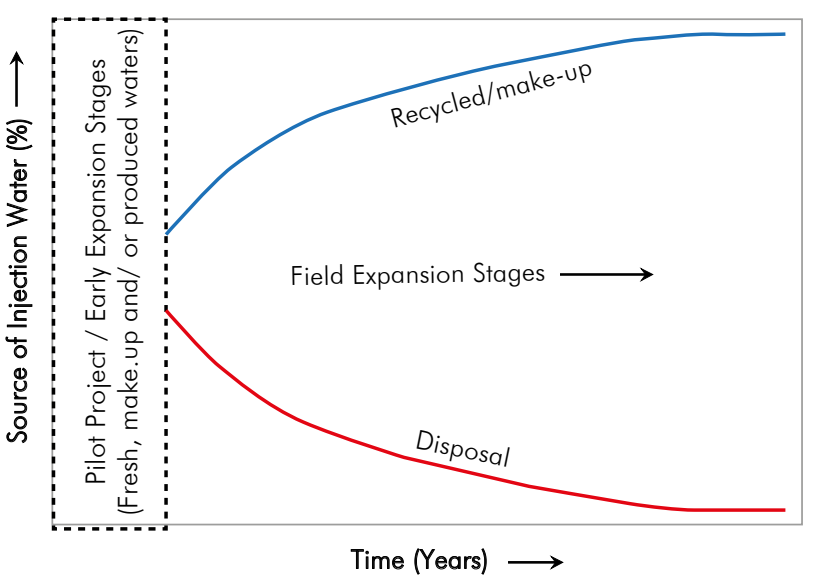

Figure 3. A schematic example of produced water utilization for injection and disposal in polymer floods from pilot scale to field expansion.

Under this scenario (Figure 3) pilot expansion by phases seems to be a better option to manage volumes of produced water and associated costs separating polymer from produced fluids including water treatment for its reinjection and/or disposal. The impact of back produced polymer on production facilities, fluid handling and treatment during polymer flooding have been well documented at lab, bench (i.e. flow loops) and field scale (Al-Kalbani, A., Mandhari, M. S., Al-Hadhrami, H., \& Philip, G., 2014b; Al-Maamari, R. S., Sueyoshi, 
M., Tasaki, M., Kojima, K., Okamura, K., 2014; Bartz \& Gotterba, 2015; Jacob et al., 2015; Rambeau, Jacob, Jouenne \& Cordelier, 2014; Zheng, Quiroga \& Sams, 2011). However, these topics will not be covered here and are out of the scope of this review.

Given the importance of pressure fall-off test (FOT) as a monitoring tool in recent polymer floods, authors of this paper consider relevant starting with a brief history of well test data interpretation of non-Newtonian fluids such as polymers. As indicated by several authors in the past, due to the rheology of the polymer its viscosity in the reservoir is a function of velocity (shear rates) at any location, polymer concentration, and its nonuniform distribution along the injection path (Huh \& Snow, 1985). The rheology of the polymers flowing through porous media could vary from Newtonian at low flow rate, pseudoplastic at intermediate flow rate, and dilatant at high flow rate (Hirasaki \& Pope, 1974). Qualitative and quantitative interpretation of polymer flooding data is relevant to infer important reservoir properties. Individual analysis of FOT, pulse test, step rate test, Hall plot and recently time lapsed temperature logs represents a good example of this approach. The application of Hall plot in polymer injection was verified by Buell, Kazemi and Poettmann (1990). The Hall plot is applicable in steady state conditions and its slope is changing during transient flow, however, it could be a qualitative plot to look at. On the other hand, pressure pulse and FOT became very popular for pressure transient analysis (PTA) before, during, and after polymer injection. However, due to the sensitivity and difficulties interpreting pressure pulse tests, FOT became the method most commonly used.

Hazebroek, Rainbow and Matthews (1958) derived the formulation of pressure fall-off test for Newtonian fluid (waterflooding) which was not appropriate for polymer flooding. Ikoku and Ramey (1979) presented an extensive differential equation for pseudoplastic non-Newtonian fluid following Ostwald de Waele power-law relationship in a homogenous reservoir. Later, Okpobiri and Ikoku (1983) studied the behavior of dilatant non-Newtonian fluid in composite reservoirs. Their results showed that the semilog straight line used for Newtonian fluid is departing from linear to upward curves as a function of flow behavior index in the power-law relationship equation. Misinterpreting the non-Newtonian as Newtonian fluids, the analysis of the semilog straight line will result as near wellbore barrier and as the fluid behavior index decreases from unity, the slope of the semilog straight line beyond wellbore storage and skin increases (Olarewaju, 1992). Ikoku and Ramey (1979) also conclude that, since the front is a moving target during the transition time and its viscosity is not constant, the application of superposition due to its non-linearity effect will lead to major errors and also some standard conventional analysis such as Horner plot may not be applicable. Kazemi, Merrill and Jargon (1972) however, proved that Horner plot can be used with caution where reservoir boundary radius is 10 times greater than the front boundary. Huh and Snow (1985) verified that the power-law formulations, which model non-Newtonian fluids, in general, underestimate the pressure due to lower resistance factor prediction at high Darcy velocity. All these conclude that the PTA of non-Newtonian fluids by itself is not as simple as standard conventional analysis for Newtonian fluids. There are many assumptions that need to be considered and complications are involved for its non-linearity behavior which makes its analysis more difficult.

It is well documented that in immiscible floods such as polymer flooding, the sweep efficiency is controlled by mobility differences of injected and displaced fluids. Due to the higher viscosity of the polymer solution compared to water viscosity, polymer injectivity is less than water and it may reach to the FFP faster than water and this could become faster as polymer concentration increases. There is always a tradeoff between injection rate and polymer concentration but one might prefer to increase the rate and not to reduce the concentration. Under the conditions of injecting below the FFP, the near wellbore velocity increases which could result in polymer degradation. On the other hand, injecting above the FFP could create induced fractures with high conductivity over some existence reservoir heterogeneity could result less polymer degradation (Clemens et al., 2013), but monitoring its growth with respect to high sweep efficiency may become a challenging task. Furthermore, since polymer viscosity is a function of the shear rate and correspondingly function of velocity, during the injection and shut-in periods (Fall Off Test) its viscosity will be different at the same distance from the wellbore or more precisely, its transient behavior for injection and shut-in periods will not be the same at the same distance from the wellbore (Mahani et al., 2011).

Despite the challenges of pressure transient analysis of non-Newtonian fluids, and moreover, recent improvements interpreting FOT to estimate fracture geometry in polymer floods (larger wellbore storages 
and negative skins), it is important to recognize that uncertainties still exist regardless the methods used. The use of tiltmeter arrays or microseismic monitoring has been also recommended to improve the understanding of fracture growth and geometries in polymer floods (Haynes et al., 2013). However, these methods not always are feasible to implement and also have its limitations to qualitatively estimate fracture dimensions (Cipolla and Wright, 2000; Maxwell, 2009; Preiksaitis, Bowman, Urbancic \& Baig, 2014; Zwaan and Valdez, 2015). An additional challenge of the proposed well tests is with large or commercial scale projects where well interferences can also play an important role estimating fracture geometries of polymer floods injecting above the FFP. Therefore, the uncertainties associated to fracture propagation and dimensions must be incorporated early in project evaluations from the geologic and numerical simulation to its potential impact on oil recoveries and polymer production (Chiotoroiu, M. M., Peisker, J., Clemens, T., \& Thiele, M., 2016; Zhou, Muggeridge, Berg \& King, 2015; Zwaan and Valdez, 2015). FOT before and after the polymer flood combined with time lapsed temperature logs combined with tiltmeter arrays or microseismic monitoring (Shuaili et al., 2012), to quantitatively analyze the fracture geometries and avoid any misinterpretation of near wellbore barriers with non-Newtonian fluid behavior, can reduce some level of the uncertainties. However, at field scale floods, interference between wells and the possible formation of in-situ emulsion will require sophisticated analysis.

\section{Water Emulsions in the Presence of Polymers}

The challenges of polymer production and its effects on oil-water emulsion stability represents a topic of great interest in recent years. However, most of the studies documented in the literature mainly focus its attention on emulsion stability and its impact on oil-water separation, water treatment and production facilities (i.e. nutshell filters, heater treaters) due to the back produced polymer (Al-Kalbani et al., 2014; Al-Maamari et al., 2014; Bartz and Gotterba, 2015; Delamaide et al., 2014b; Geremia, and Bennetzen, 2016; Jacob et al., 2015; Rambeau, O., Jacob, M., Jouenne, S., \& Cordelier, P., 2014; Wu et al., 2013; Wylde, Slayer \& Barbu, 2013; Yang, Zhihua, Xianglong \& Shanzhe, 2015; Zheng, F., Quiroga, P., \& Sams, G. W., 2011).

The response of the injection pressure represents a key monitoring variable in polymer floods. Generally, pressure increase observed in polymer injectors is associated to mobility reduction (oil bank formation), shear-thickening behavior of the injected polymer solutions (polymer rheology) and possible formation plugging effects due to poor water quality and/or polymer solubility, among others (Glasbergen G., Wever, D., Keijzer, E., \& Farajzadeh, R., 2015; Laoroongroj, A., Zechner, M., Clemens, T., \& Gringarten, A., 2012; Lin, Qiu \& Guo, 2015; Lotfollahi et al., 2015; Shuaili et al., 2012; Van den Hoek et al., 2012). However, the potential impact of the formation of oil:water emulsion in the presence of polymer (i.e. HPAM's) on well injectivity and pressure build-up response observed in polymer floods have not been fully recognized and addressed in the literature. Following sections will summarize recent evidence that can support the formation of viscous emulsions in the formation that can lead to both injectivity and productivity reduction in polymer floods.

\section{Summary discussion}

The formation of oil-water emulsions (outside or inside the porous media) in absence of chemicals used in EOR processes has been widely documented in the literature. The spontaneous emulsification of oil and water has been related to (Abou-Kassem \& Farouq Ali, 1986; Bennion, D. B., Bennion, D. W., Thomas, F. B., \& Bietz, R. F., 1998; Chakravarty, Fosbøl \& Thomsen, 2015; Cuthiell, D., Green, K., Chow, R., Kissel, G., \& McCarthy, C., 1995; Kokal, 2005; Moradi, Alvarado \& Huzurbazar, 2011; Pietrangeli, Quintero, Jones \& Darugar, 2014; Rezaei and Firoozabadi, 2014; Sjöblom et al., 2003; Sun, Mogensen, Bennetzen \& Firoozabadi, 2016; Wang and Alvarado, 2012):

- Water composition (i.e. brine salinity)

- Oil composition (i.e. asphaltenic, naphthenic and waxy crudes)

- Presence of mineral solid particles (i.e. clays and fines)

- Presence of contaminants in injection waters (i.e. surface active agents in produced waters used for its re-injection)

- Injection rates and degree of turbulence induced in situ in the porous media (i.e. injection above frac gradient)

Despite the evidence of the formation oil:water emulsion in situ during waterflood operations, these 
emulsification mechanisms in the presence of polymers have not been considered as a potential cause of injectivity reduction and/or pressure increase response observed in polymer injectors.

It is well known that the adjustment of water chemistry (i.e. lowering the ionic strength of injection waters) is frequently considered or implemented in chemical EOR including polymer flooding. This strategy will improve polymer rheological response and reduce the polymer mass required to sustain the target injection viscosity. However, it has been reported that low salinity/ionic strength brines favors the formation of stable water-inoil emulsion. For example, the laboratory evaluation of Windalia polymer flood reported the emulsion formation tendencies between the reservoir oil and different injection brines. Fletcher and Morrison (2008) reported in their study that higher salinity (TDS $=38,000 \mathrm{ppm}$ ) brine showed less emulsification tendencies than lower salinity (TDS $=29,000 \mathrm{ppm}$ ) injection brine. However, it is not clear if high polymer retention $(\geq 130 \mathrm{mg} / \mathrm{g}$ of rock) and RRF ( 8 to 45 ) values reported in this study are due to low permeability $(1.0-13.8 \mathrm{mD})$ of the reservoir core plugs used and/or the emulsification of oil-waterpolymer in-situ during the corefloods.

Some Wyoming crude oils (Minnelusa and Tensleep Fms.) are also a good example of forming stable waterin-oil emulsions in the presence of low salinity brines. Asphaltene and organic acid content have been proposed preliminarily as some of the key components present in crude oils that can contribute to the stabilization of water-in-oil emulsions under low salinity conditions (Alvarado, García-Olvera, Hoyer \& Lehmann, 2014; Moradi, M., Alvarado, V., \& Huzurbazar, S., 2011; Wang, Brandvik \& Alvarado, 2010; Wang \& Alvarado, $2008 \&$ 2012). Wang and Alvarado (2012) also reported that the emulsion stability increases with the increase of the oil-to-water ratio, suggesting the importance of the interfacial-active fractions present in oil for emulsion stability. This finding can potentially have an important impact on in-situ emulsions in the formation of oil banks during polymer floods. Results of these studies triggered the interest evaluating the impact of the presence of polymer, or lack thereof, on oil-water emulsions in some crude oils from Wyoming. Figure 4 shows preliminary results of the emulsification tendencies of two crude oils (TC and WG Fields) in the presence of EOR polymers (powder products only) in high salinity brines at room temperature.

Optical micrographs clearly show that TC oil forms good emulsions with brine and all polymer products evaluated at high salinity conditions. Instead, WG oil does not form emulsions with any of these mixtures at the same experimental conditions. On the other hand, both crude oils can form stable emulsions in the presence of low salinity brines and showed positive effects in low salinity corefloods (Alvarado, V., García-Olvera, G., Hoyer, P., \& Lehmann, T. E., 2014 and references therein). Alvarado et al. (2014) highlight the importance of asphaltene and organic acids content in crude oil to partially explain the complex emulsification behavior observed in TC and WG experiments. Although results

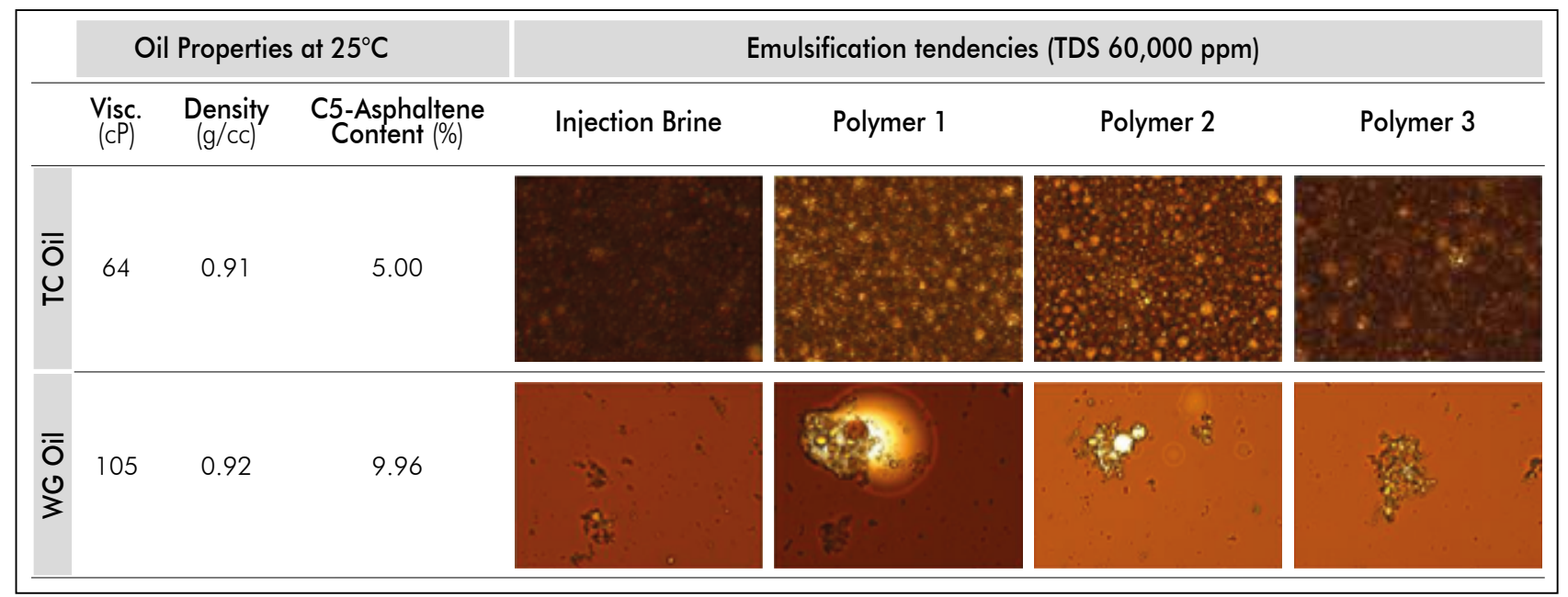

Figure 4. Example of emulsification tendencies of two Wyoming crude oils in the presence of EOR polymers in high salinity water at $25^{\circ} \mathrm{C}$ (Courtesy of Prof. Alvarado, University of Wyoming). 
of this investigation are at early stages, it is clear that some crude oils can form emulsions with water and polymers. Therefore, to include the emulsification tendencies studies in the experimental protocols during the evaluation of polymer floods is strongly recommended.

Izadi, M., Kazemi, H., Manrique, E., Kazempour, M., \& Rohilla, N., (2014) and Izadi (2015) recently reported the abnormal pressure response observed during a tertiary polymer flood experiment (Figure 5). In this research, a polymer solution was injected in 1 ft. Berea core plugs in a single phase (Figure 5a) and at irreducible oil saturation to water (Figure 5b). During the single phase, experiment polymer was injected in a water-saturated core (in absence of oil). Results of this experiment did not suggest any adverse polymer-rock interaction and the residual resistance factor reported $(\mathrm{RRF}=2.5)$ can be considered reasonable compared to those documented in the literature (Izadi, 2015; Martin, Donaruma \& Hatch, 1982). However, polymer injection in tertiary mode did show a significant pressure increase $(80 \mathrm{psi})$ and a poor incremental oil recovery $(\approx$ $3 \%$ of the OOIP) after the injection (at $0.15 \mathrm{cc} / \mathrm{min}$ ) of approximately $3 \mathrm{PV}$ and $2 \mathrm{PV}$ of polymer and brine with lower salinity (TDS $=35,000 \mathrm{ppm})$, respectively. The differential pressures $(\Delta \mathrm{P})$ reported in this experiment (Figure $5 \mathrm{~b}$ ) cannot be justified with the estimation of apparent viscosities of a polymer solution of 2,500 ppm $\left(\approx 15 \mathrm{cP} @ 10 \mathrm{~s}^{-1}\right)$. Instead, results strongly suggest the formation of an oil:polymer viscous phase causing a reduction in the permeability $(\mathrm{RRF}=8.6)$. It is also important to mention that the oil used in this study showed stable water-in-oil emulsions with the decrease in brine salinities.

Based on experiences of spontaneous oil-water emulsions well documented during the last decades, the review and evaluation of different polymer flood pilots and recent evidence briefly described in this section, formation of viscous emulsion in-situ cannot be ruled out during polymer floods. Oil-water emulsification in the presence of polymers is not well understood and can also explain polymer injectivity reduction and productivity losses reported in recent polymer floods. Additionally, formation of viscous emulsions can lead to the misinterpretation of pressure response observed in polymer injectors (i.e. formation of oil bank, shear thickening effects) during well test analysis (Olarewaju, 1992), especially when projects experience productivity losses.

\section{Productivity Losses in Polymer Floods}

Productivity loss in polymer floods represents a topic that has not been fully addressed in the literature except for few cases that will be briefly described later in this section. Most of polymer floods surveys (from 1978 to 2016) summarized earlier in this paper do not report the decrease of production rates (total fluids) in the projects reviewed. Gao (2011) reported that low productivity is one of the issues that are facing polymer flood field applications. However, this review neither provided details of potential causes of productivity losses nor specific field projects to support this statement. Standnes and Skjevrak (2014) summarized most relevant challenges and issues reported in polymer floods (i.e. corrosion, emulsion formation and mechanical

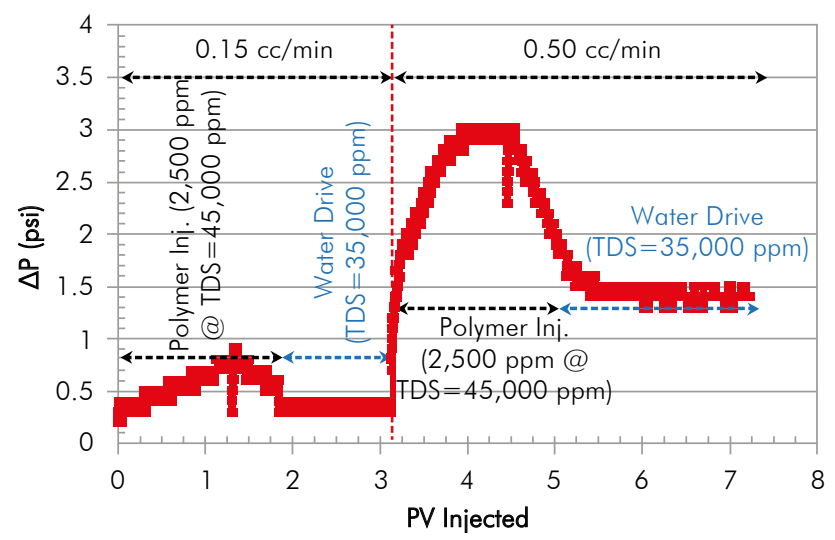

(a)

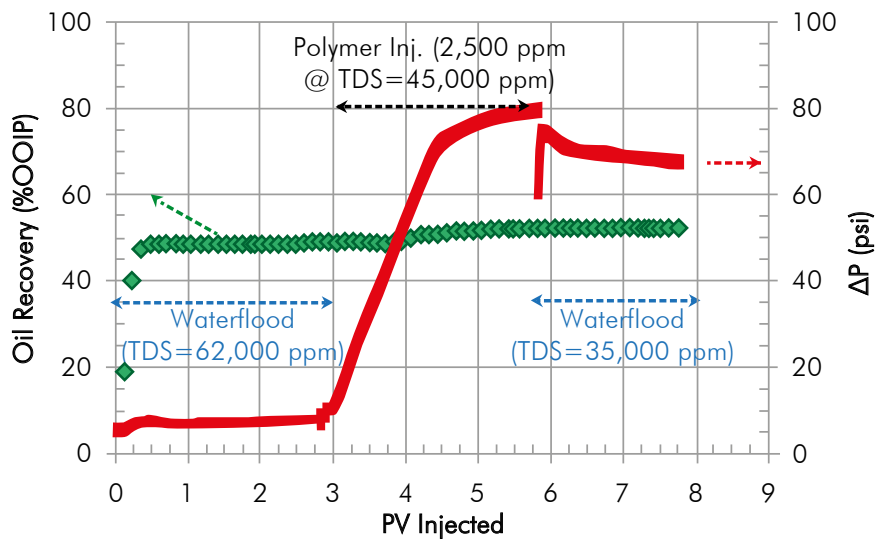

(b)

Figure 5. Pressure drop response of polymer injection in single phase (a) and tertiary mode (b) in Berea core plugs (From Izadi, 2015). 
failures) including a description of 6 discouraging cases. This review, however, did report productivity losses experienced in Bohai Bay project in China (Han, M., Xiang, W., Zhang, J., Jiang, W., \& Sun, F., 2006).

Productivity losses in polymer floods have been attributed to multiple variables and its possible combinations:

- Skin damage near wellbore (i.e. asphaltene deposition, sludge formation, etc.)

- Plugging effects due to the presence of solid fine particles

- Lower fluid withdrawal in artificial lift pump systems due to increases in fluid density in the presence of produced polymer

- Stable oil-water-polymer emulsions

Sleepy Hollow Reagan Unit (SHRU), Nebraska, is one of the polymer floods projects (mid-1980s) documenting productivity losses. Christopher, Clark and Gibson (1988) reported that despite observing incremental oil production a reduction of total liquid rates was observed with the first polymer breakthrough. Productivity losses (20\% to $50 \%)$ were mitigated with chemical treatments based on xylene and mutual solvents reporting encouraging results. Regardless the injectivity reduction ( $10 \%$ to $70 \%)$ and productivity losses observed in this project, polymer flood at SHRU was reported as a technical and economic success. It is important to mention that SHRU project used low salinity water (TDS $=718 \mathrm{ppm}$ ) to prepare and inject polymer compared to the salinity of produced brines (TDS $=32,000 \mathrm{ppm}$ ). It is not clear if fresh water injection had some influence on the injectivity and productivity behavior of this polymer flood. However, during displacement tests using sand packs permeability reduction was observed and was attributed to the presence of field crude oil (Christopher et al., 1988). This observation confirms the importance of oil:water:polymer interactions (i.e. in-situ emulsification) as described in the previous section of this paper.

Most recently, Marmul polymer flood in Oman also reported productivity losses. At least $50 \%$ of production wells have seen a reduction (5\% to $40 \%)$ in total liquid rates and reaching more than $50 \%$ in some producers.
This drop in total liquids (with minimal to no oil gain) corresponds with the high polymer production (>500 ppm) through high permeability streaks and/or fractures (Choudhuri et al., 2013; Thakuria et al., 2013). Strategies to partially restore well productivity include well stimulation with solvents and its combinations with xylene and diesel (Choudhuri et al., 2013). Well stimulation treatments have been optimized using mixtures of xylene, diesel, surfactants, and demulsifiers. Bullhead solvent treatments have been found as efficient as treatments performed with coiled tubing units reducing well interventions costs (Al-Kalbani et al., 2014a). Marmul polymer flood is also reporting challenges in production facilities (i.e. fouling in crude oil heaters), crude oil dehydration and water treatment for polymer preparation and its re-injection (Al-Kalbani et al., 2014b \& 2014c). Challenges faced in Marmul polymer flood are expected at commercial scale projects and experiences gained will contribute supporting ongoing and future pilot tests and field expansions.

Matzen (8 TH horizon) polymer flood pilot in Austria is reporting encouraging oil production response. However, this pilot test also shows a decreasing trend $(20 \%$ to $30 \%)$ in total fluid rates. However, it is not clear if this trend in well productivity losses is influenced by the decrease of pump efficiencies, injectivity reduction (i.e. reduced throughput volume) and/or polymer production (Chiotoroiu et al., 2016; Lüftenegger et al., 2015), among other possible variables.

\section{Summary discussion}

As mentioned earlier, productivity losses have not been reported in most polymer floods except for Bohai Bay (27 injectors), Sleepy Hollow Reagan Unit (10 injectors) and Marmul (27 injectors) large/ commercial scale polymer floods (Choudhuri et al., 2014; Christopher et al., 1988; Luo, Zhao \& Branch, 2011; Thakuria et al., 2013; Xiaodong et al., 2011). Mangala Field, India (Kumar, P., Raj., R., Koduru, N., Kumar, S., \& Pandey, A., 2016) and Patos-Marinza, Albania (Bankers, 2016; Carss, 2014; Jacobs, 2015) are also recent large polymer floods but there is a lack of information documenting polymer production and/ or possible productivity losses. However, Mangala polymer flood is reporting strategies to improve well injectivity and productivity (i.e. add perforations, reperforations, pump changes, wellbore cleanouts and well 
stimulation) in underperforming patterns suggesting some level of productivity issues (Kumar et al., 2016).

If productivity losses are attributed to polymer production, it is expected to see larger drops in total liquid rates in commercial scale polymer floods due to the level of confinement of multiple producers and polymer mass injected/produced during the project. However, as of today, there are not enough documented field data to support that all polymer floods will experience productivity losses due to high polymer production. Hence, more detailed studies evaluating oil:water:polymer interactions at different experimental conditions (i.e. oil:water ratios, polymer concentration and water strategies) to better understand emulsification tendencies and its impact on the performance of polymer floods will be required.

Monitoring changes of total fluid rates in offset producers combined with water compositional analysis, polymer production and well events (i.e. stimulation, pump changes, etc.) represent a common practice in polymer floods. However, there are some scenarios where the identification of possible losses in total fluid rates can be challenging:

- Polymer losses in unconfined pilot patterns such as Matzen Field (Laoroongroj et al., 2015; Lüftenegger et al., 2015), Tambaredjo Field (Manichand et al., 2013) and Yariguí-Cantagallo Field (Maya et al., 2015) to just mention a few. This can lead to lower polymer production reducing the probability of reaching a potential threshold limit (if any) to cause productivity losses.

- Viscous oil reservoirs with low or a decreasing trend in productivity under primary recovery or waterflooding. Generally, this type of reservoir shows an increase in productivity as a response of polymer injection being El Corcobo Field (Hryc et al., 2013), Pelican Lake / Brintnell project (Delamaide et al., 2014b), Tambaredjo Field (Delamaide et al., 2016) some good examples of this behavior. However, increases in oil rates observed during polymer injection can mask slight decrease in total fluid production, especially in horizontal producers such as in Medicine Hat Glauconitic C Pool (Batonyi et al., 2016) and Suffield Caen (Liu et al., 2012) polymer floods.
Despite the productivity losses documented in Bohai Bay, Marmul and SHRU polymer floods, these projects have been reported as technical and economic successes (Al-Saadi et al, 2014; Christopher et al., 1988; Xiaodong et al., 2011). Additionally, Choudhuri et al. (2014) reported the optimization of the current phase (27 patterns) of the polymer flood based on streamline simulation. The main objective of this study was to evaluate individual patterns under polymer injection identifying underperforming patterns that were converted to water injection ( 3 patterns), another pattern that improved its efficiency after a conformance job and the rest were ranked to optimize polymer injection by adjusting injection rates, slug size and/or polymer concentration. Ranking of existing patterns under water injection to be converted to polymer flooding was also evaluated in this study as part of Marmul Field project expansion.

Based on the experiences in Bohai Bay, Marmul and SHRU polymer floods, it can be concluded that productivity losses and polymer production are challenges that can be managed. However, productivity losses and polymer production can strongly influence project economics, especially when evaluating polymer flood expansions. Some of the operational expenditures (OPEX) associated with productivity losses and polymer production is summarized below:

- Incremental downhole costs due to failures in artificial lift systems (i.e. rod breaks) pumping higher viscosity fluids (Batonyi et al., 2016).

- Production of tight emulsions that generally increase crude oil separation costs. For example, Marmul project reports an increase of demulsifier concentration from $10 \%$ to $30-50 \%$ to break produced fluids in the presence of polymer (AlKalbani et al., 2014b).

- Impact on surface facilities (i.e. scale deposit on heat exchangers, nutshell filters, heater treaters) due to back produced polymer (Al-Kalbani et al., 2014b; Bartz and Gotterba, 2015; Riethmuller et al., 2014; Wylde, J., Slayer, J. L., \& Barbu, V., 2013).

- Water treatment costs required to meet water quality standards for polymer preparation, water re-injection and/or water disposal (Al-Kalbani et al., 2014c; Al-Maamari et al., 2014; Batonyi et 
al., 2016; Henthorne, Walsh \& Llano, 2013; Jacob et al., 2015; Rambeau et al., 2014 \& 2015; Wu et al., 2013; Yang, L., Zhihua, W., Xianglong, Z., \& Shanzhe, W., 2015).

- Workovers and well stimulation to restore well productivity (Al-Kalbani et al., 2014a; Choudhuri et al., 2013; Christopher et al., 1988; Kumar et al., 2016).

Reviewing recent studies evaluating the economics of polymer flooding it can be concluded that OPEX described above is generally underestimated (Alkhatib, 2015; AlSofi and Blunt, 2011; Behr, Olie, Visser \& Leonhardt, 2013; Botechia, Correia \& Schiozer, 2016; Mogollón, Tillero, Gutiérrez \& Luján, 2016; Raniolo, S., Dovera, L., Cominelli, A., Callegaro, C., and Masserano, F., 2013; Sieberer et al., 2016). Mogollón and Lokhandwala (2013) presented an example of polymer flood economics using a broad range of costs to potentially cover high OPEX based on a probabilistic approach. However, literature's lack of studies evaluating the impact of productivity losses on project economics (i.e. delay in final incremental oil recoveries, deferred production due to shut-in producers, more realistic OPEX supported by ongoing field experiences). This is an area that requires more attention when performing economic evaluations of polymer floods, especially for field expansions and offshore applications. Additionally, variables such as fiscal regimes (i.e. taxes, royalties, production sharing agreements) and associated costs (CAPEX and OPEX) can vary significantly in different countries and potentially influence polymer flood economics.

Finally, it is important to recognize some of the limitations forecasting the incremental oil recovery of polymer floods. The generation and upscaling of geologic models represent a common uncertainty in reservoir simulation studies. History matching approaches of primary and water injection can also impact the prediction of polymer injection. Input variables required to predict polymer flood performance are also part of the uncertainties that needs to be considered in simulation studies (Aldhuwaihi, King \& Muggeridge, 2015; Alkhatib, 2015; AlSofi and Blunt, 2011; Chiotoroiu et al., 2016; Fabbri et al., 2015; Romero et al., 2013; Skauge and Salmo, 2015; Skauge et al., 2016; Zhou, Y., Muggeridge, A. H., Berg, C. F., \& King, P. R., 2015). Additionally, commercial simulation tools still have some limitations to properly represent the potential formation of in-situ emulsions and its impact on well injectivity/productivity. Therefore and despite the incremental oil recoveries and successes reported in multiple polymer floods, there are areas that require more attention to further improve polymer flood economics.

\section{CONCLUSIONS}

- Polymer flooding has been successfully implemented worldwide and its applicability has been expanded to low permeability and highly viscous oil reservoirs. However, most of the field applications are in onshore sandstone formations. Field experiences of polymer injection in high temperature, offshore and carbonate reservoirs are still limited.

- Injectivity reduction should be expected during polymer flooding. Most polymer floods are operating at VRR close to one addressing injectivity reduction using horizontal injectors, different well stimulation strategies and reducing polymer concentration/ viscosity (trade-off between mobility control and injectivity). Therefore, injecting higher polymer concentrations is not necessarily better. More recently, few polymer floods reported the use of injection rates above the formation fracture pressure to mitigate injectivity losses. However, uncertainties associated with fracture propagation and impact on polymer production of this injection strategy still remain.

- Polymer production should be also expected in polymer floods, especially at large or commercial scale. However, OPEX associated to oil-water separation in the presence of polymer and productivity losses (i.e. workovers, stimulation costs) are generally underestimated and must be considered during project economic evaluations. These costs might not be too important at pilot scale but will be critical for largescale polymer floods, especially if the project will rely on produced water for polymer preparation and its re-injection.

- The impact of oil geochemistry/composition and water salinity on oil:water:polymer emulsions is commonly overlooked in polymer flood studies. The formation of in-situ emulsions can also explain the injectivity and/or productivity reduction and well test 
interpretation (i.e. FOT) reported in polymer floods. Changes of injection water strategies, chemical treatments and polymer products during a polymer flood may impact project economics. Therefore, the influence of oil composition, polymer type and quality, injection water salinity/hardness and its chemical treatment on oil-water-polymer emulsions must be incorporated at early stages of laboratory studies.

- Polymer floods is still a promising chemical EOR technology, however, great opportunities exist for improving project economics by optimizing polymer injection, water strategy and reducing operating costs.

\section{REFERENCES}

Abdullah, M., Tiwari, S., \& Pathak, A. (2015). Evolution of chemical EOR (ASP) program for a carbonate reservoir in North Kuwait. SPE Middle East Oil \& Gas Show and Conference, Manama, Bahrain, 8-11. SPE-172608.

Abou-Kassem, J. H., Farouq Ali, S. M. (1986). Flow of nonNewtonian fluid in porous media. SPE Eastern Regional Meeting, Columbus, Ohio. SPE-15954.

Al Azri, N. (2012). Polymer Flooding in a large field in South Oman - initial results and future plans. SPEATW: Chemical Flooding, Penang, Malaysia. DOI: 10.2118/154665-MS

Alberta Energy Regulator (1994). Directive 051: Injection and Disposal Wells - Well classifications, completions, logging, and testing requirements. Available in $<\mathrm{https} / / \mathrm{www}$.aer.ca/ documents/directives/Directive051.pdf $>$.

Alberta Energy Regulator (2014). Directive 065: Resources Applications for Oil and Gas Reservoirs, [Consulted: April 9 of 2017]. Available in:

$<\mathrm{http} / / /$ www.aer.ca/documents/directives/Directive065.pdf>

Aldhuwaihi, A., King, P., \& Muggeridge, A. H. (2015). Upscaling polymer flooding to model sub-gridblock geological heterogeneity and compensate for numerical dispersion. 18th European Symposium on Improved Oil Recovery, Dresden, Germany. Paper Th A15.

Al-Kalbani, A., Chandan, T., Saqri, K., Ravula, C., Choudhuri, B., Hashmi, K. (2014a). Solvent stimulation to restore productivity of polymer pattern producer wells - a case study. SPE EOR Conference at Oil and Gas West Asia, Muscat, Oman. SPE-169714.

Al-Kalbani, A., Mandhari, M. S., Al-Hadhrami, H., \& Philip, G. (2014b). Impact on crude dehydration due to back production of polymer. SPE EOR Conference at Oil and Gas West Asia, Muscat, Oman. SPE-169718.

Al-Kalbani, A., Mandhari, M. S., Al-Hadhrami, H., Philip, G., Nesbit, J., Gil, L., \& Gaillard, N. (2014c). Treating back produced polymer to enable use of conventional water treatment technologies. SPE EOR Conference at Oil and Gas West Asia, Muscat, Oman. SPE-169719.

Alkhatib, A. (2015). Chemical EOR Strategy Optimization in the Presence of Economic and Technical Uncertainty (Paper We A01). 18th European Symposium on Improved Oil Recovery, Dresden, Germany.

Al-Maamari, R. S., Sueyoshi, M., Tasaki, M., Kojima, K., Okamura, K. (2014). Polymer-Flood Produced Water Treatment Trials (SPE-172024-PA). Oil and Gas Facilities, 3(6), 89-100. DOI: 10.2118/172024-MS.

Al-Saadi, F. S., Al-Subhi, H. A., \& Al-Siyabi, H. (2014). Recovery Factor Estimation in EOR Polymer Flood Project: Field Case. SPE EOR Conference at Oil and Gas West Asia, Muscat, Oman. SPE-169694.

Al-Saadi, F. S., Amri, B. A., Nofli, S., Van Wunnik, J., Jaspers, H. F., Harthi, S., Shuaili, K., Cherukupalli, P. K., \& Chakravarthi, R. (2012). Polymer flooding in a large field in South Oman - Initial results and future plans. SPE EOR Conference at Oil and Gas West Asia, Muscat, Oman. SPE-154665.

AlSofi, A. M, \& Blunt, M. J. (2011). The design and optimization of polymer flooding under uncertainty (Paper A08). 16th European Symposium on Improved Oil Recovery, Cambridge, UK.

Alvarado, V., García-Olvera, G., Hoyer, P., \& Lehmann, T. E. (2014). Impact of polar components on crude oil-water interfacial film formation: a mechanism for low salinity waterflooding. SPE Annual Technical Conference and Exhibition, Amsterdam, The Netherlands. SPE-170807.

Alvarado, V., \& Manrique, E. (2013). Engineering design challenges and opportunities beyond waterflooding in offshore reservoirs. Offshore Technology Conference, Houston, TX, OTC-24104. 
Baker, R. (1998). Reservoir management for waterfloods Part II. The Journal of Canadian Petroleum Technology, 37 (1). 12-17.

Bankers (2016). Bankers Petroleum Operational Update for the Second Quarter 2016. Bankers Petroleum Ltd, July 6th. Available in <http://www.bankerspetroleum.com/ investing/news-releases/bankers-petroleum-operationalupdate-second-quarter-2016>.

Bartz, D., \& Gotterba, J. (2015). Results of the field operation of a distributed-flux burner in a heater treater in a Northern Canada heavy oil field: Thermal performance and firetube life (spe-170172-pa). Oil and Gas Facilities, 4(3), 97-104. DOI: 10.2118/170172-PA.

Batonyi, A., Thorburn, L., Molnar, S. (2016). A Reservoir Management Case Study of a Polymer Flood Pilot in Medicine Hat Glauconitic C Pool (SPE-179555). SPE Improved Oil Recovery Conference, Tulsa, OK, April 11-13.

Behr, A., Olie, L., Visser, F., \& Leonhardt, B. (2013). Optimization of polymer flooding with a tapered concentration slug (Paper P10). 17th European Symposium on Improved Oil Recovery, St. Petersburg, Russia.

Bennion, D. B., Bennion, D. W., Thomas, F. B., \& Bietz, R. F. (1998). Injection water quality - a key factor to successful waterflooding. The Journal of Canadian Petroleum Technology, 37 (6), 53-62. DOI: 10.2118/94-60.

Botechia, V. E., Correia, M. G., \& Schiozer, D. J. (2016). A model-based production strategy selection considering polymer flooding in heavy oil field development. SPE Trinidad and Tobago Section Energy Resources Conference, Port of Spain, Trinidad and Tobago. SPE-180838.

Brice, B., Ning, S., Wood, A., \& Renouf, G. (2014). Optimum voidage replacement ratio and operational practice for heavy oil waterfloods. SPE Heavy Oil Conference-Canada, Alberta, Canada. SPE-170099.

Buciak, J., Sancet, G. F., \& Del Pozo, L. (2015). PolymerFlooding-Pilot Learning Curve: Five-Plus Years' Experience to reduce cost per incremental barrel of oil (SPE-166255PA). SPE Reservoir Evaluation \& Engineering, 18(1), 11-19. DOI:10.2118/166255-PA.

Buell, R. S., Kazemi, H., \& Poettmann, F. H. (1990). Analyzing Injectivity of Polymer Solutions With the Hall Plot (SPE-
16963-PA). SPE Reservoir Engineering, 5(1), 41-46. DOI:10.2118/16963-PA.

Bursaux, R., Sophie Peltier; Michel Nguyen; Carolina, Romero \& Danielle, Morel. (2016). Single Well Tracer Test results in a high temperature, high salinity offshore carbonate reservoir for chemical EOR Pilot Evaluation. SPE Improved Oil Recovery Symposium, Tulsa, OK. SPE-179579. DOI: 10.2118/179579-MS.

Carss, R. (2014). Future Development in Patos-Marinza Oilfield - The largest onshore heavy oil field in continental Europe. Presentation at the 6th Oil Forum of Energy Community Meetings, Belgrade, Serbia, Sept. 30th. Available in $<$ https://www.energy-community.org/portal/page/portal/ ENC_HOME/INST_AND_MEETINGS?event_reg. category $=\mathrm{E} 13940>$.

Chakravarty, K. H., Fosbøl, P. L., \& Thomsen, K. (2015). Brine crude oil interactions at the oil-water interface. SPE Enhanced Oil Recovery Conference, Kuala Lumpur, Malaysia. SPE-174685.

Chang, H. L. (1978). Polymer flooding technology - yesterday, today and tomorrow (SPE-7043-PA). Journal of Petroleum Technology, 1113-1128.

Chevron. (2014). Chevron North Sea Awards Captain Enhanced Oil Recovery (EOR) Project Contracts to United Kingdom Suppliers. Available in: <http://www. chevronunitedkingdom.com/news/latest/2014-12-15-eorcontracts-uk.aspx $>$.

Chevron. (2015). Supplement to the Annual Report. Available in <https://www.chevron.com/-/media/chevron/shared/ documents/annual-report-supplement-2015.pdf $>$.

Chiotoroiu, M. M., Peisker, J., Clemens, T., \& Thiele, M. (2016). Forecasting Incremental Oil Production of a Polymer Pilot Extension in the Matzen Field Including Quantitative Uncertainty Assessment. SPE Improved Oil Recovery Symposium, Tulsa, OK. SPE-179546.

Choudhuri, B., \& Al-Rawahi, M. (2008). Success Story of a Waterflood Project in a Geologically Complex, HighViscosity Oil Reservoir in a Major Brownfield in South Oman (SPE-105245-PA). SPE Reservoir Evaluation \& Engineering, 11(3), 620-632. 
Choudhuri, B., Kalbani, A., Cherukupalli, P. K., Ravula, C., Hashmi, K., \& Jaspers, H. (2013). Enhancing value of polymer flood project with proactive well and reservoir management. SPE Enhanced Oil Recovery Conference, Kuala Lumpur, Malaysia. SPE-165274.

Choudhuri, B., Thakuria, C., Belushi, A. A., Nurzaman, Z., Hashmi, K., \& Batycky, R. (2014). Optimization of a large polymer flood using full-field streamline simulation. SPE EOR Conference at Oil and Gas West Asia, Muscat, Oman. SPE-169746.

Christopher, C. A., Clark, T. J., \& Gibson, D. H. (1988). Performance and Operation of a successful polymer flood in the sleepy hollow reagan unit. SPE/DOE Enhanced Oil Recovery Symposium, Tulsa, OK. SPE-17395.

Cipolla, C. L., \& Wright, C. A. (2000). State-of-the-Art in Hydraulic Fracture Diagnostics. SPE Asia Pacific Oil and Gas Conference and Exhibition, Brisbane, Australia. SPE-64434.

Clemens, T., Deckers, M., Kornberger, M., Gumpenberger, T., \& Zechner, M. (2013). Polymer solution injection - near wellbore dynamics and displacement efficiency, pilot test results, Matzen Field, Austria. EAGE Annual Conference \& Exhibition - SPE EUROPEC, London, UK. SPE-164904.

Cuthiell, D., Green, K., Chow, R., Kissel, G., \& McCarthy, C. (1995). The In Situ Formation of heavy oil emulsions. SPE International Heavy Oil Symposium, Calgary, Canada. SPE-30319.

Delamaide, E. (2014). Polymer flooding of heavy oils - from screening to full field extension. SPE Heavy and Extra Heavy Oil Conference, Latin America, Medellin, Colombia. SPE-171105.

Delamaide, E., Bazin, B., Rousseau, D., \& Degre, G. (2014a). Chemical EOR for heavy oil: the Canadian experience. SPE EOR Conference at Oil and Gas West Asia, Muscat, Oman. SPE-169715.

Delamaide, E., Moe, K., Bhoendie, K., Jong-A-Pin, S., \& Paidin, W. R. (2016). Results of a polymer flooding pilot in the Tambaredjo heavy oil field, Suriname. SPE Canada Heavy Oil Technical Conference, Calgary, Canada. SPE180739.

Delamaide, E., Tabary, R., Rénard, G., \& Dwyer, P. (2014b). Field Scale Polymer Flooding of Heavy Oil: The Pelican
Lake Story. 21st World Petroleum Congress, Moscow, Russia. WPC 21-0851.

Delamaide, E., Zaitoun, A., Renard, G., \& Tabary, R. (2013). Pelican Lake Field: First Successful application of polymer flooding in a heavy-oil reservoir. SPE Enhanced Oil recovery Conference, Kuala Lumpur, Malaysia. SPE165234.

Delgado, D. E., Vittoratos, E., \& Kovscek, A. R. (2013). Optimal Voidage Replacement Ratio for Viscous and Heavy Oil Reservoirs. SPE Western Regional \& AAPG Pacific Section Meeting - Joint Technical Conference, Monterey, CA. SPE-165349.

Du, Y., \& Guan, L. (2004). Field-scale polymer flooding: lessons learnt and experiences gained during past 40 years. SPE International Petroleum Conference, Puebla, Mexico. SPE-91787.

Dwarakanath, V., Dean, R. M., Slaughter, W., Alexis, D., Espinosa, D., Kim, D. H., Lee, V., Malik, T., Winslow, G., Jackson, A. C., \& Thach, S. (2016). Permeability reduction due to use of liquid polymers and development of remediation options. SPE Improved Oil Recovery Conference, Tulsa, OK. SPE-179657.

Fabbri, C., de Loubens, R., Skauge, A., Ormehaug, P. A., Vik, B., Bourgeois, M., Morel, D., \& Hamon, G. (2015). Comparison of history-matched water flood, tertiary polymer floods relative permeabilities and evidences of hysteresis during tertiary polymer flood in very viscous oils. SPE Asia Pacific Enhanced Oil Recovery, Kuala Lumpur, Malaysia. SPE-174682.

Fletcher, A. J. P., \& Morrison, G. R. (2008). Developing a Chemical EOR Pilot Strategy for a Complex, Low Permeability Water Flood. SPE/DOE Improved Oil Recovery Symposium, Tulsa, OK. SPE-112793.

Gaillard, N., Giovannetti, B., Leblanc, T., Thomas, A., Braun, O., \& Favero, C. (2015). Selection of customized polymers to enhanced oil recovery from high temperature reservoirs. SPE Latin American and Caribbean Petroleum Engineering Conference, Quito, Ecuador. SPE-177073.

Gao, C. H. (2011). Advances of Polymer Flood in Heavy Oil Recovery. SPE Heavy Oil Conference and Exhibition, Kuwait City, Kuwait. SPE-150384. 
Geremia, G., \& Bennetzen, M. V. (2016). An Operational Workflow for EOR Polymer Trials. SPE EOR Conference at Oil and Gas West Asia, Muscat, Oman. SPE-179785.

Glasbergen G., Wever, D., Keijzer, E., \& Farajzadeh, R. (2015). Injectivity loss in polymer floods: causes, preventions and mitigations. SPE Kuwait Oil \& Gas Show and Conference, Kuwait City, Kuwait. SPE-175383.

Han, M., Fuseni, A., Zahrani, B., \& Wang, J. (2014). Laboratory study on polymer for chemical flooding in carbonate reservoirs. SPE EOR Conference at Oil and Gas West Asia, Muscat, Oman. SPE-169724.

Han, M., Xiang, W., Zhang, J., Jiang, W., \& Sun, F. (2006). Application of EOR Technology by means of polymer flooding in Bohai oil fields. SPE International Oil \& Gas Conference and Exhibition, Beijing, China, SPE-104432.

Haynes, A. K., Clough, M. D., Fletcher, A. J. P., \& Weston, S. (2013). The successful implementation of a novel polymer EOR pilot in the low permeability Windalia Field. SPE Enhanced Oil Recovery Conference, Kuala Lumpur, Malaysia, SPE-165253.

Hazebroek, P., Rainbow, H., \& Matthews, C. S. (1958). Pressure Fall-Off in Water Injection Wells (SPE-925-G). Petroleum Transactions AIME, 213, 250-260.

Henthorne, L., Walsh, J., \& Llano, V. (2013). Water Management for EOR Applications - Sourcing, Treating, Reuse and Recycle. Offshore Technology Conference, Houston, TX, May 6-9. OTC-24199.

Hirasaki, G. J., \& Pope, G. A. (1974). Analysis Factors Influencing Mobility and Adsorption in the Flow of Polymer Solution Through Porous Media (SPE-4026-PA). Society of Petroleum Engineers Journal, 14(4), 337-346. DOI:10.2118/4026-PA.

Hryc, A., Hochenfellner, F., Paponi, H., Puliti, R., \& Gerlero, T. (2013). Design and Execution of a Polymer Injection Pilot in Argentina. SPE Annual Technical Conference and Exhibition, New Orleans, LA. SPE-166078.

Huh, C., \& Snow, T. M. (1985). Well Testing With a NonNewtonian Fluid in the Reservoir. 60th Annual Technical Conference and Exhibition, Las Vegas, NV. SPE-14453.
Ikoku, C. U., \& Ramey, H. J. (1979). Transient Flow of NonNewtonian Power-Law Fluids in Porous Media (SPE7139-PA). Society of Petroleum Engineers Journal, 19(3), 164-174. DOI:10.2118/7139-PA.

Izadi, M. (2015). Assessing productivity impairment of surfactant-polymer EOR using laboratory and field data. PhD Thesis Petroleum Engineering, Colorado School of Mines, 90pp.

Izadi, M., Kazemi, H., Manrique, E., Kazempour, M., \& Rohilla, N. (2014). Microemulsion Flow in Porous Media: Potential Impact on Productivity Losses. SPE EOR Conference at Oil and Gas West Asia, Muscat, Oman. SPE-169726.

Jacob, M., Demangel, A., Goldszalu, A., Rambeau, O., Jouenne, S., \& Cordelier, P. (2015). Impact of back produced polymer on tertiary water treatment performances. SPE Enhanced Oil Recovery Conference, Kuala Lumpur, Malaysia. SPE174683.

Jacobs, T. (2015). Reviving Europe's largest onshore field (SPE-0315-0070-JPT). Journal of Petroleum Technology, 67(3), 70-74. DOI: 10.2118/0315-0070-JPT.

Jouenne, S., Chakibi, H., \& Levitt, D. (2015). Polymer Stability Following Successive Mechanical Degradation Events. 18th European Symposium on Improved Oil Recovery, Dresden, Germany. Paper Th B01.

Kazemi, H., Merrill, L. S., \& Jargon, J. R. (1972). Problems in interpretation of pressure fall-off tests in reservoirs with and without fluid banks (SPE-3696-PA). Journal of Petroleum Technology, 24(9), 1147-1156. DOI:10.2118/3696-PA.

Khatib, Z. I., \& Salanitro, J. P. (1997). Reservoir souring: analysis of surveys and experience in Sour waterfloods. SPE Annual Technical Conference and Exhibition, San Antonio, TX. SPE-38795.

Khodaverdian, M., Sorop, T., Postif, S., \& Van den Hoek, P (2010). Polymer flooding in unconsolidated-sand formations: fracturing and geomechanical considerations (SPE-121840-PA). SPE Production \& Operations, 25(2), 211-222. DOI: 10.2118/121840-PA.

Kokal, S. L. (2005). Crude Oil Emulsions: a state-of-the-art review (SPE-77497-PA). SPE Production \& Facilities, 20(1), 5-13. DOI: 10.2118/77497-PA. 
Koning, E. J. L., Mentzer, E. (1988). Evaluation of a Pilot Polymer Flood in the Marmul Field, Oman. 63rd Annual Technical Conference and Exhibition of the SPE, Houston, TX. SPE-18092.

Kumar, P., Raj., R., Koduru, N., Kumar, S., \& Pandey, A. (2016). Field implementation of mangala polymer flood: initial challenges, mitigation and management. SPE EOR Conference at Oil and Gas West Asia, Muscat, Oman. SPE-179820.

Laoroongroj, A., Lüftenegger, M., Kadnar, R., Puls, C., \& Clemens, T. (2015). Using tracer data to determine polymer flooding effects in a heterogeneous reservoir, 8th Reservoir, Matzen Field, Austria. SPE EUROPEC, Madrid, Spain. SPE-174349.

Laoroongroj, A., Zechner, M., Clemens, T., \& Gringarten, A. (2012). Determination of the In-Situ Polymer Viscosity from Fall-Off Tests. SPE EUROPEC/EAGE Annual Conference, Copenhagen, Denmark. SPE-154832.

Larter, S. R., \& Aplin, A. C. (1995). Reservoir geochemistry: methods, applications and opportunities. The geochemistry of reservoirs, Geological Society Special Publication, 86, 5-32. DOI: 10.1144/GSL.SP.1995.086.01.02.

Levitt, D., Klimenko, A., Jouenne, S., Passade-Boupat, N., Cordelier, P., Morel, D., \& Bourrel, M. (2016). Designing and injecting a chemical formulation for a successful OffShore Chemical EOR pilot in a high-temperature, high salinity, low-permeability carbonate field. SPE Improved Oil Recovery Symposium, Tulsa, OK. SPE-179679.

Lin, J., Qiu, K., \& Guo, X. (2015). Application of Well Test Information to Judge Blocking and Channeling in Polymer Flood Unit. SPE Enhanced Oil Recovery Conference, Kuala Lumpur, Malaysia. SPE-174670.

Liu, J., Adegbesan, K., \& Bai, J. (2012). Suffield Area, Alberta, Canada - Caen polymer flood pilot project. SPE Heavy Oil Conference Canada, Calgary, Canada. SPE-157796.

Lotfollahi, M., Farajzadeh, R., Delshad, M., Al-Abri, K., Wassing, B. M., Mjeni, R., Awan, K., \& Bedrikovetsky, P. (2015). Mechanistic simulation of polymer injectivity in field tests. SPE Enhanced Oil Recovery Conference, Kuala Lumpur, Malaysia. SPE-174665.

Lüftenegger, M., Kadnar, R., Puls, C., \& Clemens, T. (2015). Operational Challenges and Monitoring of a Polymer Pilot,
Matzen Field, Austria. EUROPEC 2015, Madrid, Spain. SPE-174350. DOI: 10.2118/174350-PA.

Luo, X., Zhao, C., \& Branch, T. (2011). Practices and experiences of seven-year polymer flooding history matching in China offshore oil field: a Case Study. SPE Reservoir Characterization and Simulation Conference and Exhibition, Abu Dhabi, U.A.E. SPE-147807.

Mahani, H., Sorop, T., Van den Hoek, P., Brooks, D., \& Zwaan, M. (2011). Injection Fall-Off Analysis of Polymer Flooding EOR. SPE Reservoir Characterization and Simulation Conference and Exhibition, Abu Dhabi, U.A.E. SPE145125 .

Manichand, R. N., Moe, K. P., Gil, L., Quillien, B., \& Seright, R. S. (2013). Effective propagation of HPAM solutions through the Tambaredjo reservoir during a polymer flood (SPE-164121-PA). SPE Production \& Operations, 28(4), 358-368. DOI: 10.2118/164121-PA.

Manichand, R. N., \& Seright, R. S. (2014). Field vs. Laboratory Polymer-Retention Values for a Polymer Flood in the Tambaredjo Field (SPE-169027-PA). SPE Reservoir Evaluation \& Engineering, 17(3), 314-325. DOI: 10.2118/169027-PA.

Manichand, R., Mogollón, J. L., Bergwijn, S., Graanoogst, F., \& Ramdajal, R. (2010). Preliminary assessment of tambaredjo heavy oilfield polymer flooding pilot test. SPE Latin American and Caribbean Petroleum Engineering, Lima, Peru. SPE-138728.

Manning, R. K., Pope, G. A., Lake, L. W., \& Willhite, P. (1983). A technical survey of polymer flooding projects. U.S. Department of Energy, Report DOE/BC/10327-19.

Manrique, E., Muci, V. E., \& Gurfinkel, M. E. (2007). EOR Field experiences in carbonate reservoirs in the United States (SPE-100063-PA). SPE Reservoir Evaluation \& Engineering, 667-686. DOI: 10.2118/100063-MS.

Martin, F. D., Donaruma, L. G., \& Hatch, M. J. (1982). Development of improved mobility control agents for surfactant/polymer flooding. final report DOE/BC/0004719.

Masalmeh, S., Wei, L., Blom, C., \& Jing, X. (2014). EOR Options for Heterogeneous Carbonate Reservoirs Currently Under Waterflooding. Abu Dhabi International Petroleum Exhibition and Conference, Abu Dhabi, UAE. SPE-171900. 
Maxwell, S. (2009). Assessing the impact of microseismic location uncertainties on interpreted hydraulic fracture geometries. SPE Annual Technical Conference and Exhibition, New Orleans, LA. SPE-125121.

Maya, G., Jiménez, R., Castro, R., Mantilla, J., Vargas, J., Cárdenas, F., Fernández, F., Quintero, H., Zaitoun, A., Manrique, E., Romero, J., \& Putnam, J. (2015). Design and Implementation of the First Polymer Flooding Project in Colombia: Yariguí-Cantagallo Field. SPE Latin American and Caribbean Petroleum Engineering Conference, Quito, Ecuador. SPE-177245.

Moe, K. P., Manichand, R. N., \& Seright, R. S. (2012). Polymer Flooding a $500-\mathrm{cP}$ Oil. SPE Improved Oil Recovery Symposium, Tulsa, OK. SPE-154567.

Mogollón, J. L., \& Lokhandwala, T. (2013). Rejuvenating viscous oil reservoirs by polymer injection: lessons learned in the field. SPE Enhanced Oil Recovery Conference, Kuala Lumpur, Malaysia. SPE-165275.

Mogollón, J. L., Tillero, E., Gutiérrez, I., Luján, L. (2016). Numerical maximization of the secondary polymer flooding value in a mature, offshore, heavy oil reservoir. Offshore Technology Conference, Houston, TX. OTC-27189.

Moradi, M., Alvarado, V., \& Huzurbazar, S. (2011). Effect of salinity on water-in-crude oil emulsion: evaluation through drop-size distribution proxy. Energy \& Fuels, 25(1), 260268. DOI: $10.1021 / \mathrm{ef101236h}$.

Morel, D., C., Zaugg, E., Jouenne, S., Danquigny, J. A., \& Cordelier, P. R. (2015). Dalia/Camelia polymer injection in deep offshore field Angola learnings and in situ sampling results. SPE Enhanced Oil Recovery Conference, Kuala Lumpur, Malaysia. SPE-174699.

Morel, D., Vert, M., Jouenne, S., Gauchet, R., \& Bouger, Y. (2012). First Polymer injection in deep offshore field Angola: Recent Advances in the Dalia/Camelia Field Case (SPE-135735-PA). Oil and Gas Facilities, 1(2), 43-52. DOI:10.2118/135735-PA.

Needham, R. B., \& Doe, P. H. (1987). Polymer Flooding Review (SPE-17140-PA). Journal of Petroleum Technology, 15031507.

Nurmohamed, D., Chin, H., Lien, A., \& Kisoensingh, S. (2014). Case study for reducing tubing failures in Suriname's Tambaredjo Field. SPE Biennial Energy Resources Conference, Port of Spain, Trinidad. SPE-169978.
Okpobiri, G. A., \& Ikoku, C. U. (1983). Pressure transient analysis behavior of dilatant non-newtonian/newtonian fluid composite reservoirs. Eastern Regional Meeting, Pittsburgh, PA. SPE-12307.

Olarewaju, J. S. (1992, January 1). A Reservoir Model of NonNewtonian Fluid Flow (SPE-25301). Society of Petroleum Engineers.

Pietrangeli, G., Quintero, L., Jones, T., \& Darugar, Q. (2014). Treatment of Water in Heavy Crude oil emulsions with innovative microemulsion fluids. SPE Heavy and Extra Heavy Oil Conference, Medellin, Colombia. SPE-171410.

Poulsen, A. (2009). Chemical EOR Implementation for the captain field, UK (Abstract \& Presentation B2). 30th Annual Workshop and Symposium International Energy Agency Collaborative Project on EOR, Canberra, Australia.

Poulsen, A. (2010). The Captain Polymer EOR Pilot. 31st Annual Workshop and Symposium International Energy Agency Collaborative Project on EOR, Aberdeen, Scotland, Oct. 18-20. Presentation F4.

Preiksaitis, M., Bowman, S., Urbancic, T., \& Baig, A. (2014). Utilizing Microseismic Stress Release to Identify Out-ofZone Fracture Growth. SPE Annual Technical Conference and Exhibition, Amsterdam, The Netherlands. SPE-170938.

Rambeau, O., Alves, M-H, Loriau, M., Molinier, V., PassadeBoupat, N., \& Lebas, G. (2015). chemical solutions to handle viscosified back produced water in case of polymer flooding. SPE Abu Dhabi International Petroleum Exhibition and Conference, Abu Dhabi, U.A.E. SPE177501.

Rambeau, O., Jacob, M., Jouenne, S., \& Cordelier, P. (2014). A tool to tackle the challenges of the treatment of the back produced viscosified water. International Petroleum Technology Conference, Doha, Qatar. IPTC-17626.

Raniolo, S., Dovera, L., Cominelli, A., Callegaro, C., Masserano, F. (2013). History match and polymer injection optimization in a mature field using the ensemble kalman filter. 17th European Symposium on Improved Oil Recovery, St. Petersburg, Russia. Paper B23.

Raza, S. M., Shoaib, M., Al Sumaiti, A. M., \& Al Hassan, S. M. (2015). Screening polymers for EOR in high temperature, 
high salinity and carbonate reservoir conditions. International Petroleum Technology Conference, Doha, Qatar. IPTC-18436.

Renouf, G. (2014). A Survey of Polymer Flooding in Western Canada. SPE Improved Oil Recovery Symposium, Tulsa Oklahoma. SPE-169062.

Rezaei, N., \& Firoozabadi, A. (2014). Macro- and microscale waterflooding performances of crudes which form w/o emulsions upon mixing with brines. Energy \& Fuels, 28(3), 2092-2103. DOI:10.1021/ef402223d.

Riethmuller, G., Abri, A., Al Azri, N., Stapel, G., Nijman, S., Subhi, W., \& Rawa, M. (2014). opportunities and challenges of polymer flooding in heavy oil reservoir in South of Oman. SPE EOR Conference at Oil and Gas West Asia, Muscat, Oman. SPE-169737.

Romero, C., Aubertin, F., Fabbri, C., Nguyen, M., Hourcq, S., \& Hamon, G. (2013). Secondary polymer flooding in extra-heavy oil core experiments under reservoir conditions and core scale simulations. 17th European Symposium on Improved Oil Recovery, St. Petersburg, Russia. Paper B02.

Saboorian-Jooybari, H., Dejam, M., \& Chen, Z. (2015). HalfCentury of Heavy Oil Polymer flooding from laboratory core floods to pilot tests and field applications. SPE Canada Heavy Oil Technical Conference, Calgary, Canada. SPE174402.

Saleh, L. D., Wei, M., \& Bai, B. (2014). Data analysis and updated screening criteria for polymer flooding based on oilfield data (SPE-168220-PA). SPE Reservoir Evaluation \& Engineering, 17(1), 15-25. DOI:10.2118/168220-PA.

San Blas, P., \& Vittoratos, E. (2014). The polymer in polymer flooding: is its value overestimated? SPE Heavy Oil Conference-Canada, Alberta, Canada. SPE-170104.

Seright, R. (2010). Potential for Polymer Flooding Reservoirs With Viscous Oils (SPE-129899-PA). SPE Reservoir Evaluation \& Engineering, 13(4), 730-740. DOI:10.2118/129899-PA.

Sheng, J. J., Leonhardt, B., \& Azri, N. (2015). Status of Polymer-Flooding Technology (SPE-174541-PA). Journal of Canadian Petroleum Technology, 116, 126. DOI:10.2118/174541-PA.
Shuaili, K., Cherukupalli, P. K., Al-Saadi, F. S., Al-Hashmi, K., Jaspers, H. F., \& Sen, S. (2012). fracture growth monitoring in polymer injectors - field examples. SPE Conference at ADIPEC, Abu Dhabi, U.A.E. SPE-160967.

Sieberer, M., Jamek, K., \& Clemens, T. (2016). Polymer Flooding Economics, from Pilot to Field Implementation at the Example of the 8 TH Reservoir, Austria. SPE Improved Oil Recovery Symposium, Tulsa, OK. SPE-179603.

Sjöblom, J., Aske, N., Auflem, I. H., Brandal, Ø., Havre, T. E., Sæther, Ø., Westvik, A., Johnsen, E. E., \& Kallevik, H. (2003). Our current understanding of water-in-crude oil emulsions: Recent characterization techniques and high pressure performance. Advances in Colloid and Interface Science, 100-102, 399-473. DOI:10.1016/S00018686(02)00066-0.

Skauge, A., \& Salmo, I. (2015). Relative Permeability Functions for Tertiary Polymer Flooding (Paper Th A14). 18th European Symposium on Improved Oil Recovery, Dresden, Germany.

Skauge, T., Skauge, A., Salmo, I. C., Ormehaug, P. A., AlAzri, N., Wassing, L. M., Glasbergen, G., Van Wunnik, J. N., \& Masalmeh, S. K. (2016). Radial and linear polymer flood - influence on injectivity. SPE Improved Oil Recovery Symposium, Tulsa, OK. SPE-179694.

Skauge, T., Vik, B. F., Ormehaug, P. A., Jatten, B. K., Kippe, V., Skjevrak, I., Standnes, D. C., \& Uleberg, K. (2014). Polymer flood at adverse mobility ratio in $2 \mathrm{D}$ flow by X-ray visualization. SPE EOR Conference at Oil and Gas West Asia, Muscat, Oman. SPE-169740.

Sorbie, K. S. (1991). Polymer-Improved Oil Recovery. Glasgow \& London, Blackie and Son Ltd.

Standnes, D. C., \& Skjevrak, I. (2014). Literature review of implemented polymer field projects. Journal of Petroleum Science and Engineering, 122, 761-775. DOI: http://dx.doi. org/10.1016/j.petrol.2014.08.024.

Sun, M., Mogensen, K., Bennetzen, M., \& Firoozabadi, A. (2016). Demulsifier in Injected Water for improved oil recovery of crudes that form water/oil emulsions (SPE180914-PA). SPE Reservoir Evaluation \& Engineering, 19(4), 664-672. DOI:10.2118/180914-PA. 
Terrado, M., Yudono, S., \& Thakur, G. (2006). Waterflooding surveillance and monitoring: putting principles into practice. SPE Annual Technical Conference and Exhibition, San Antonio, TX, SPE-102200.

Thakur, G. C., \& Satter, A. (1998). Integrated Waterflood Asset Management. Oklahoma, PennWell.

Thakuria, C., Amri, M., Saqri, K., Jaspers, H., Hashmi, K., \& Zuhaimi, K. (2013). Performance review of polymer flooding in a major brown oil field of Sultanate of Oman. SPE Enhanced Oil Recovery Conference, Kuala Lumpur, Malaysia, SPE-165262.

Van den Hoek, P., Mahani, H., Sorop, T., Brooks, D., Zwaan, M., Sen, S., Shuaili, K., \& Saadi, F. (2012). Application of injection fall-off analysis in polymer flooding. SPE EUROPEC/EAGE Annual Conference, Copenhagen, Denmark, SPE-154376.

Vittoratos, E. S., Coates, R., \& West, C. C. (2011). Optimal voidage replacement ratio for communicating heavy oil waterflood wells. SPE Heavy Oil Conference and Exhibition, Kuwait City, Kuwait. SPE-150576.

Vittoratos, E. S., Zhu, Z., \& West, C. C. (2014). Optimal waterflood voidage management significantly increases oil recovery with minimal incremental cost. SPE Abu Dhabi International Petroleum Exhibition and Conference, Abu Dhabi, U.A.E. SPE-171937.

Vittoratos, E., \& Boccardo, G. (2015). Heavy Oil Waterflooding Enable by Optimal Waterflood Voidage Management. 18th European Symposium on Improved Oil Recovery, Dresden, Germany. Th B14.

Wang, X., \& Alvarado, A. (2008). Effect of Salinity and pH on Pickering Emulsion Stability. SPE Annual Technical Conference and Exhibition, Denver, CO, SPE-115941.

Wang, X., \& Alvarado, A. (2012). Effects of Aqueous-Phase Salinity on Water-in-Crude Oil Emulsion Stability. Journal of Dispersion Science and Technology, 33(2), 165-170. DO I:10.1080/01932691.2010.548689.

Wang, X., Brandvik, A., \& Alvarado, V. (2010). Probing Interfacial Water-in-Crude Oil Emulsion Stability Controls Using Electrorheology. Energy \& Fuels, 24(12), 6359-6365. DOI:10.1021/ef1008874.
Wu, D., Meng, X., Zhao, F., Lin, S., Jiang, N., Zhang, S., Qiao, L., \& Song, H. (2013). Dual function reverse demulsifier and demulsifier for the improvement of polymer flooding produced water treatment. International Petroleum Technology Conference, Beijing, China. IPTC-16594.

Wylde, J., Slayer, J. L., \& Barbu, V. (2013). Polymeric and Alkali-Surfactant Polymer Enhanced oil recovery chemical treatment: chemistry and strategies required after breakthrough into the process. SPE International Symposium on Oilfield Chemistry, The Woodlands, TX. SPE-164078.

Xiaodong, K., Jian, Z. Fujie, S., Fengjiu, Z., Guozhi, F., Junru, Y., \& Xiansong, Z. (2011). A review of polymer EOR on offshore heavy oil field in Bohai Bay, China. SPE Enhanced Oil Recovery Conference, Kuala Lumpur, Malaysia. SPE144932.

Yang, L., Zhihua, W., Xianglong, Z., \& Shanzhe, W. (2015). Study on Emulsification Behavior and optimized separation technology of high concentration polymer flooding produced liquid in daqing oilfield. SPE Middle East Oil \& Gas Show and Conference, Manama, Bahrain, SPE-172768.

Zechner, M., Clemens, T., Suri, A., \& Sharma, M. M. (2015). Simulation of polymer injection under fracturing condition - an injectivity pilot in the Matzen Field, Austria (SPE169043-PA). SPE Reservoir Evaluation \& Engineering, 18(2), 236-249.

Zhang, Y., Wei, M., Bai, B., Yang, H., \& Kang, W. (2016). Survey and data analysis of the pilot and field polymer flooding projects in China. SPE Improved Oil Recovery Symposium, Tulsa, OK. SPE-179616.

Zheng, F., Quiroga, P., \& Sams, G. W. (2011). Challenges in processing produced emulsion from chemical enhanced oil recovery - polymer flood using polyacrylamide. SPE Enhanced Oil Recovery Conference, Kuala Lumpur, Malaysia. SPE-144322.

Zhou, J., Dong, Y., de Pater, C. J., \& Zitha, P. L. J. (2010). Experimental Study of the Impact of shear dilation and fracture behavior during polymer injection for heavy oil recovery in unconsolidated reservoirs (CSUG/ SPE-137656). Canadian Unconventional Resources \& International Petroleum Conference, Calgary, Canada. 
Zhou, Y., Muggeridge, A. H., Berg, C. F., \& King, P. R. (2015). Quantifying Viscous Cross-flow and its impact on tertiary polymer flooding in heterogeneous reservoirs (Paper Th B02). 18th European Symposium on Improved Oil Recovery, Dresden Germany.

Zhuoyan, Z., Quan, X., Hanbing, X., Jian, F., Feng, W., Juedu, A., Vermolen, C. M., Lingli, W., Hon, C. L., Shemin, S., \& Dehai, H. (2015). Evaluation of the potential of high temperature, low-salinity polymer flood for the Gao-30 reservoir in the Huabei Oilfield, China: Experimental and Reservoir Simulation Results (OTC-25817). Offshore Technology Conference, Houston, TX, May 4-7.

Zwaan, M., \& Valdez, R. (2015). Chemical and miscible gas EOR field development strategies based on integrated surveillance interpretation. SPE Kuwait Oil and Gas Show and Conference, Mishref, Kuwait. SPE-175285.

\section{AUTHORS}

\section{Eduardo Manrique}

Affiliaton: MI3 Petroleum Engineering, Colorado, United States of America.

e-mail: emanrique@mi3pe.com

\section{Mahmood Ahmadi}

Affiliaton: MI3 Petroleum Engineering, Colorado, United States of America.

e-mail: mahmadi@mi3pe.com

\section{Shirin Samani}

Affiliaton: MI3 Petroleum Engineering, Colorado, United States of America.

e-mail: ssamani@mi3pe.com 
